\title{
COVID-19 Algılanan Stres ve Tehdidinin, Çalışanların İş Yaşam Dengesi ve Motivasyonu Üzerindeki Etkisi ${ }^{1}$
}

\author{
Effect of COVID-19 Perceived Stress and Threat on Employee Work Life \\ Balance and Motivation
}

Büşra YILMAZ ${ }^{2}$, Mehmet SAĞLAM ${ }^{3}$

\begin{abstract}
Öz
Amaç: $\mathrm{Bu}$ çalışmada COVID-19'un yarattığı stres ve tehdit algısının, çalışanların iş yaşam dengesi ve motivasyonu üzerindeki etkisinin incelenmesi amaçlanmıștır.

Tasarım/Yöntem: Araştırmada basit tesadüfî örnekleme yöntemi kullanılmıştır. Veri analizleri için SPSS 22.0 ve LISREL 8.7 istatistik paket programlarından yararlanılmıştır Google Forms'ta tasarlanan online anket yöntemi ile 390 katılımcıya ulaşılmıştır.

Bulgular: Araştırma sonucunda algilanan stres ve tehdidin, çalışanların iş yaşam dengesi ve motivasyonunu anlamlı bir şekilde etkilediği saptanmıştır. Stresin iş yaşam dengesi ve motivasyon alt boyutlarının tümü üzerinde pozitif yönlü etkisi olduğu, tehdidin ise iş yaşam dengesi alt boyutlarının tümü üzerinde negatif, motivasyon alt boyutlarında ise sadece yönetsel motive araçları üzerinde negatif yönlü etkisi olduğu sonucuna ulaşılmıştır.

Sınırlılıklar: Çalışmanın 15 Nisan 2021-13 Haziran 2021 tarihleri aralığında yürütülmesi ve veri analizinin 390 katılımcı üzerinden gerçekleştirilmesi çalışmanın zaman ve kapsam sınırını olușturmaktadır.

Özgünlük/Değer: COVID-19 salgını hakkında çalışmalar yapılmasına karşın algılanan stresin ve tehdidin, çalışanların iş yaşam dengesi ve motivasyonuna etkisinin incelenerek işletmelerin çalışanlara yönelik stratejilere katkı sağlayabilecek sonuçlara ulașılması, araștırmanın özgün değerini oluşturmaktadır.

Anahtar Kelimeler: COVID-19, Stres, Tehdit, İş Yaşam Dengesi, Motivasyon
\end{abstract}

\begin{abstract}
Purpose: In this study, it was aimed to examine the effect of stress and threat perception caused by COVID-19 on the work-life balance and motivation of employees.

Design/Methodology: Simple random sampling method was used in the research. For data analysis, SPSS 22.0 and LISREL 8.7 statistical package programs were used and applied to 390 participants using the online survey method designed in Google Forms.

Findings: As a result of the research, it was found that perceived stress and threat significantly affect the work-life balance and motivation of employees. It was concluded that stress has a positive directional effect on all of the work-life balance and motivation subdimensions, while the threat has a negative directional effect on all of the work-life balance sub-dimensions and only on managerial motivational tools in the motivation sub-dimensions.

Limitations: Conducting the study between April 15, 2021, and June 13, 2021, and performing the data analysis on 390 participants constitute the time and scope limitation of the study.

Originality/Value: Although studies have been conducted on the covid-19 outbreak, the effect of perceived stress and threat on employees ' work-life balance and motivation is examined and the results that can contribute to the strategies of businesses for employees are the original value of the research.

Keywords: COVID-19, Stress, Threat, Work-Life Balance, Motivation
\end{abstract}

\footnotetext{
${ }^{1}$ Bu makale birinci yazarın İstanbul Ticaret Üniversitesi Sosyal Bilimler Enstitüsü’nde Dr. Öğr. Üyesi Mehmet SAĞLAM danışmanlığında hazırlanan "COVID-19 Algılanan Stres ve Tehdidinin, Çalışanların İş Yaşam Dengesi ve Motivasyonu Üzerindeki Etkisi” isimli yüksek lisans tezinden üretilmiş̧tir. Ayrıca bu makale 8.Uluslararası Avrasya Zirvesi Bilimsel Araştırmalar ve Güncel Gelişmeler Kongresi'nde özet bildiri olarak sunulmuştur.

2 Yüksek Lisans Öğrencisi, İstanbul Ticaret Üniversitesi, Sosyal Bilimler Enstitüsü, İşletme Ana Bilim Dalı, busraylmazz97@gmail.com, ORCID: 0000-0001-8783-8401

${ }^{3}$ Dr. Öğr. Üyesi, İstanbul Ticaret Üniversitesi, İşletme Fakültesi, İşletme Bölümü, msaglam@ ticaret.edu.tr, ORCID: 00000002-1909-4284
} 


\section{GİRIŞ̧}

Dünya Sağlık Örgütü, Çin'den başlayarak Dünya'nın dört bir yanında hızlı ve çok şiddetli bir şekilde yayılan COVID-19 pandemisini 30 Ocak 2020 tarihinde "Uluslararası Boyutta Halk Sağlığ Acil Durumu" ve 11 Mart 2020 tarihinde de "Küresel Salgın" şeklinde ilan etmiştir (Hatun vd., 2020). Dünya genelinde ise küresel salgın olarak adlandırılan COVID-19'un etkilerini en aza indirmek için farklı adımlar atılmıştır (Küçükoğlu \& Aksu, 2020). Atılan bu adımlar, sadece özel yaşama yönelik olmayıp; iş dünyası, çalışan bireyler ve işletmelerde de olumsuz etkilerinin görülmesi sonucunda çalışma modellerinde uygulanan değişiklikleri de içermektedir. Bu kapsamda, pandemi sürecinde şirketler; çalışan sağlığını tehlikeye atmamak ve ayakta kalabilmek için uzaktan/evden ya da esnek/dönüşümlü çalıșma sistemine geçiş sağlamıștır. Böylece pandemi öncesinde uzaktan çalıșmanın uygulandığı iş yerlerinin yanı sıra, daha öncesinde bu çalışma modelini deneyimlememiş iş yerleri de uzaktan çalışma şekline entegre olmaya çalışmıştır.

İnsan kaynakları danışmanlık firması olan ve 130 dünya ülkesinde etkinlik gösteren Mercer Türkiye'nin (2020) yaptığı araştırmaya göre, şirketlerin \%45 oranında salgın öncesi dönemde de uzaktan çalışma yöntemini farklı bir seçenek olarak kullandığı, fakat salgın ile beraber \%95'inin merkez işyerleri başta olmak üzere uzaktan çalışma modeline geçtikleri gözlenmiştir. İşletmelerin \%36'sı saha çalışanlarını da kapsayan uzaktan çalışma modelini uygulamaya koymuşlardır. İşletmelerin \%66'sının esnek çalışma saati modeline geçerken, \%60'ının ise dolaylı pandemi bittikten sonra da esnek ve uzaktan çalışma sistemlerini uygulamaya devam edeceği görülmüştür (Duran, 2020).

Çok kısa sürede tüm dünyayı etkisi altına alan salgının, ölümlere neden olmasının yanında bireylerde stres ve tehdit kaynağı olarak hayat1; fiziksel, psikolojik, ekonomik anlamda olumsuz etkilediği gözlemlenmiştir. Bu süreçte yaşanan salgının olumsuz etkileri, devam eden belirsiz süreç, karantina uygulamaları, çalışma modellerinde yapılan düzenlenmeler; bireylerde kaygı, stres, korku ve tehdit seviyesini arttırmıştır.

Stres, çağdaş topluluklarda gündelik hayatta yoğun bir şekilde hissedilen, insan hayatının vazgeçilmez bir parçasıdır. Bireyleri bedenen ve ruhen olumsuz etkilemektedir. Salgın sürecinde algılanan stres düzeyinin yüksekliği, COVID-19'un yaratacağı olumsuz etkileri artırabilmektedir. Göksu ve Kumcağız (2020) yaptıkları çalışmada, koronavirüs salgın süreci boyunca bireylerin stres seviyelerinde artış olduğunu ve kaygı düzeylerinin yükseldiğini tespit etmişlerdir. Ayrıca katılımcıların \%84'ünün bu fikri destekleyerek stres seviyelerinin arttığını belirtmişlerdir.

Pandemi süreci için alınan tedbirler, bireylerin özel yaşam alışkanlıklarında ani değişikliğe sebep olmasının yanında iş yaşamlarını ve çalışma şekillerini de etkilemiştir. Salgın öncesinde işyaşam dengesini kurmaya çalışan bireyler salgın döneminde bu dengeyi kurmakta daha çok zorluk çekmektedir. Bireylerin salgın durumlarında stres, kaygı, korku düzeyleri artmakta, bu tür durumlar bir tehdit olarak algılanmakta ve çalışma hayatı üzerinde iş yaşam dengesini ve motivasyonu da önemli derecede etkilemektedir. Stres, kayg1, korku, algılanan tehdit vb. kaynaklı oluşan psikolojik etkilerle karşılaşılması durumunda çalışanların motivasyonu ve iş yaşam dengesi de önemli derecede değişmiştir. Hem işin hem de özel yaşamın evin içinde olması, evde yapılacak olan birçok işin kesintiye uğramasına neden olmuştur. Bu durum, iş yaşam dengesini bozmakta, çalışanın yetişmeyen işleri için daha uzun süreyle ve gece geç saatlere kadar çalışmak zorunda kalması kaygıya ve strese yol açmaktadır.

Yapılan bazı çalışmalarda kaygının motivasyonu olumlu etkilediği işaret edilmesine karşın COVID-19 pandemisi birçok belirsizliği beraberinde getiren bir salgın olmasından dolayı kontrolsüz kayg1 yaratma ihtimali yüksektir ve bunun kişinin enerjisini tüketerek motivasyonunu düşürmesi beklendiği belirtilmiştir (Tekin, 2020). Çalışma, "COVID-19 sürecinde çalışanların yaşadığı stres ve tehdit düzeylerinin iş yaşam dengesi ve motivasyon düzeyleri üzerinde ne yönde etki etmektedir" sorusuna cevap aramaktadır. Bu kapsamda hazırlanan çalışmada, COVID-19 döneminde çalışanların stres ve algılanan tehdit düzeylerinin iş yaşam dengesi ve motivasyonları üzerindeki etkisi incelenmeye çalışılmıştır. Bu çalışmada ikinci bölümde kavramsal çerçeve, üçüncü bölümde hipotez geliştirme, dördüncü bölümde araştırma metodolojisi ve beşinci bölümde ise sonuca yer verilmiştir. Araştırmada yer alan veriler, Google Forms'ta tasarlanan online anket yöntemi kullanılarak elde 
edilmiştir. Araştırmanın analiz kapsamında; demografik özelliklere ilişkin frekans analizine, açımlayıcı ve doğrusal faktör analizine, güvenirlik ve geçerlilik analizine, normallik test sonuçlarına, korelasyon analizine ve hipotezlerin test edilmesi için yapısal eşitlik modeline yer verilmiştir. Araştırma sonucunda elde edilen bulgular değerlendirilmiş ve sonuçlar yorumlanmıştır. Çalışmayı diğer araştırmalardan ayıran nokta, daha öncesinde benzer nitelikte bir çalışmanın yapılmamış olması ve pandemi döneminde yapılması ile birlikte pandemi bittikten sonra da farklı bakış açılarıyla değerlendirebilir olmasıdır.

\section{KAVRAMSAL ÇERÇEVE}

\subsection{COVID-19 Dönemi}

COVID-19 olarak adlandırılan ve virüsün bireyler arasında yayılmasıyla salgın olarak kabul edilen koronavirüs, evvela Çin'in Wuhan Eyaleti'nde hasta olan bir grup insanda tespit edilmiş, Çin'den sonra tüm dünyaya yayılarak küresel bir kriz meydana getirmiştir. COVID-19 pandemisinin bütün dünya ülkelerinde politik, psikolojik, iktisadi, fiziksel ve sosyal alanlarda çok geniş etkileri olmuştur. Salgın karşısında toplum sağlığı önerileri ve hükümet önlemleri daha çok sokağa çıkma yasağı, sosyal izolasyon ve karantina gibi bireyleri kısıtlayan uygulamalar devreye girmiştir (Yüce \& Muz, 2021). Bu süreçte bireylerin hem özel hem de iş hayatları değişim göstermiş, farklı çalışma modelleri ortaya çıkmıştır.

Dünya çapında virüsün yayılmasını önlemek için uçuşların durdurulması, sınırların kapatılması, iş yerlerinin faaliyetlerini geçici süreliğine durdurması ve uzaktan çalışmaya geçilmesi, eğitim alanında çevrimiçi sisteme geçilmesi vb. tedbirler alınmış ve alınan bu tedbirler insanların yaşam tarzlarında, alışkanlıklarında ani değişimlere neden olmuş; aşırı stres, korku, kaygı, tehdit ve çaresizlik hissinin oluşmasına yol açmıştır.

COVID-19 salgınının kesin olarak kanıtlanmış bir tedavisi henüz bulunamamıştır (TBB, 2020). Hastalığın sağlık başta olmak üzere sosyal, ekonomik, psikolojik etkileri ve yansımaları devam etmekte, yeni gelişen mutasyonlu virüs ile birlikte kesin çözümlü bir tedavinin olmayış1, sürecin ne zaman son bulacağına dair belirsizlik göstermekte ve buna ilişkin kesin veriler bulunamamaktadır.

\subsection{COVID-19 Stresi ve Algılanan Tehdidi}

İnsan sosyal bir varlıktır ve toplum ile bir bütün halindedir. Uygulanan kisttlamalar, karantina süreci, salgın beraberinde oluşan yeni ve ani düzen, insan doğası için alışılmışın dışındadır ve haliyle insan psikolojisine etkileri de kaçınılmazdır. Özellikle de uygulanan kısıtlamalarla günlük hareketliliğimizin azalması ile gerekli enerjiyi harcayamıyor olmak fiziksel ve psikolojik hastalığa neden olmuştur. $\mathrm{Bu}$ süreçte bireylerde yoğun stres, kayg1 ve bunalım gibi olumsuz etkiler gözlemlenmiştir. Hastalığın kesin bir tedavisinin olmayışı ile insanların yakınlarını kaybetmesi ve kaybetme korkusu, virüsün kişinin kendisine ve sevdiklerine buluşma endişesi, virüsün belli bir süre havada kalması gibi etkenler bireylerin yaşamlarında tehdit oluşturur hale gelmiştir.

Geçmişte yaşanan salgın hastalıklara bakıldığında hastalığa yakalanan bireylerde ortaya çıkan belirtilerin benzerlik göstermediği görülmektedir. COVID-19 sürecinde yaşanan stresin bireylerde davranış farklılıklarının olmasıyla beraber ülkede alınan tedbirler de bu farklılıkların oluşması noktasında önemli bir yere sahiptir. Geçmiş salgın tarihinde İspanyol gribi, kolera vb. hastalıklarda bu şekilde tedbirler alınmamıştır. İnsanlar ilk defa karantina sürecine dâhil olmuş, pandeminin başında bu durumla daha baş edilebilir gibiyken bireyler zamanla bu süreçten sıkılmaya başlamışlardır. Her geçen gün belirsizliğin devam etmesiyle de korku, stres ve kaygıları artmaya başlamıştır. Aynı zamanda hayatı tehdit altına alan salgınlar bireylerde iç dünyalarına kapanma, başka kişilerle araya mesafe koyma ve sosyalleşmenin azalmasına yol açmıştır. Yaşanabilecek bir salgın tehdidi ile karşı karşıya kalan bireylerin sergileyecekleri davranışlar, hastalığın bulaşma ve yayılma hızını minimum seviyeye indirgemek ve bu sebeple olabilecek ölümleri azaltmak açısından önem ifade etmektedir (Kumcağız \& Göksu, 2020).

\section{3. İş Yaşam Dengesi}

İş-yaşam dengesi, iş yerinde yapılan uygulamalar ile çalışanın özel hayatı ve iş hayatının ihtiyaçları giderilecek şekilde dengede olmasıdır. İş-yaşam dengesi, sadece bireyin işi ve özel yaşamı 
arasındaki dengeyi değil daha fazlasını ifade etmektedir. İş ve yaşam arasındaki uyumu, bireyin iş ve özel yaşam etkinlikleri arasında bir denge kurması olarak dikkate almak gerekir. Bu bağlamda işyaşam dengesi, kişinin iş ve özel hayatındaki tüm bireylere yönelik taleplerinin dengelenmesidir (Bekmezci vd., 2021).

COVID-19'un hayatımıza girmesiyle günlük yaşantımızda tercih ettiğimiz önceliklerimizden, gittiğimiz yerlere, çalışma şekillerimize kadar köklü değişimler yaşanmış ve bu değişimler özel yaşamı etkilediği kadar çalışma hayatına da yansımıştır. Şirketler çalışan sağlığının önemi ve sosyal izolasyon için evden/uzaktan veya esnek/dönüşümlü çalışma modellerine geçiş sağlamıştır. Süreçle birlikte değişen bu çalışma modelleri ile bireyin ailesiyle daha çok zaman geçirme, yolda geçen zaman kaybının ortadan kalkması, işe gidip gelirken toplu taşıma kullanma kaynaklı virüs buluşma riskinin azalması vb. avantajları olduğu gibi dezavantajları da olmuştur. Bireyin özel yaşamı ve iş yaşamının aynı evin içinde olması, evin çalışma ortamına uygun olmaması, yaşanabilecek teknik aksaklıklar, evde yapılması gereken birden fazla işin var olması, yüz yüze görüşmeme vb. durumlardan kaynakl1 iş yaşam dengesi problemleri yaşanabilmektedir.

Alınan tedbirlerin özel yaşama adapte edilmesinde güçlük çekilirken, çalışma hayatına adapte edilmesi de bir o kadar zor olabilmektedir. Evden çalışan bireylerin, yetişmeyen işlerinden dolayı daha fazla mesai yapıyor olması, ailesine olan sorumluluklarını yerine getirmesini kısıtlamaktadır. İşe veya eve ayrılan zamanın daha fazlası olması, kişinin kendisine ayırdığı zamanda azalma yaşanması vb. durumunda iş-yaşam dengesi tehlikeye girmekte ve hatta iş yaşam dengesizliğine neden olabilmektedir.

\section{4. Çalışan Motivasyonu}

Kurum kaynakları açısından önemli yere sahip olan insan kaynağı, işletmenin başarılı bir yönetim stratejisine sahip olabilmesi için, şüphesiz idare tarafından destek görmeleri ve motive edilmeleri gereken mühim bir konudur. Şirket yöneticileri, ilmi yönetim prensipleri sınırlarında bütün çalışan bireylerin motivasyonunun arttırılmasından doğrudan doğruya sorumludurlar (Uysal vd., 2019). Örgütteki her birey farklılığa alışıtır ve herkesin motivasyon algısının farklı olduğu bilinmektedir. Yöneticilerin, bu farklılıklar açısından çalışanlarını çok iyi analiz edip motivasyon kaynaklarını çözümlemesi gerekmektedir. Bir diğer taraftan da çalışanın motivasyonunu düşüren etkenler tespit edilmeli ve ortadan kaldırılması için gerekli aksiyonlar alınmalıdır.

İşletme kendi amaçlarını ve çalışanlarının amaçlarını, hedefleri doğrultusunda ortak paydada buluşturmalı, çalışanların arzu ve isteklerini göz önünde bulundurarak motive etmelidir. Çalışanın motivatörü terfi, prim, ödül, takdir edilme vb. araçlardır. İşletme, örgütteki çalışanların motivasyon araçlarını doğru tespit eder ve doğru bir şekilde uygulayabilirse motive olan çalışanın performansı ve verimliliği de artacaktır. Bu noktada çalışan motivasyonu son derece önemlidir, yeterince motive olmamış bir çalışanın aynı doğrultuda performansı da düşecek ve işletmenin olumsuz etkilenmesine neden olacaktır. Özellikle de içinde bulunduğumuz salgın döneminde oluşan yeni düzen ile birçok işletmenin kapanma riski, hastalığın şu anda öngörülen bir tedavisinin olmayışı, yeni iş ortamları ve değişken konjonktürel durumdan kaynaklı işten çıkarmalar ve sürecin belirsizliği insanları kaygılandırmakta ve çalışanın motivasyonu düşürmektedir.

\section{HIPOTEZ GELISTTIRME}

\subsection{Stres ve İş Yaşam Dengesi İliş̧kisi}

İnsan doğası her geçen gün değişen yaşam koşullarına ayak uydurmaya çalışmaktadır. Değişken yapıda olan iş ve özel yaşam alanına sağlıklı zaman ayırmaya çalışan bireyler için bu dengenin sağlanması, COVID-19 döneminde büyük önem taşımaktadır. İş ve özel yaşamın birbiriyle sürekli etkileşim halinde olması ise yaşamın kaçınılmaz bir parçası olan stresi de beraberinde getirmektedir. İş hayatında yaşanan stres arttıkça, özel yaşam alanında da stres artacak, bu durum işyaşam dengesizliğini meydana getirecektir. Aynı şekilde iş yaşam dengesizliğinin oluşması da stres seviyesini yükseltecektir.

Karabay (2015: 128), çalışanların iş veya aileden dolayı yaşadıkları stresin, işe devamsızlığı meydana getirirken, iş-aile çatışmasının bireylerin işten ayrılma niyetine etkisi olduğunu belirtmektedir. Günay ve Demiralay'ın (2016) yapmış oldukları araştırmanın sonucunda, bireyin aile 
yaşamına öncelik tanımasının, işini ihmal etmesine ve gereken özeni göstermemesine neden olacağı ifade edilmiş, bu durumun da çalışanın iş stresi yaşamasına ya da olumsuz tutumlar sergilemesine ortam hazırlayacağı belirtilmiştir. Özdemir'in (2017) yapmış olduğu çalışmada gemi adamlarında yaşanan iş stresinin artış göstermesinin iş yaşam dengesi üzerinde olumsuz yönde etkisi olduğu tespit edilmiştir. Yavuz ve Doğan'ın (2018) araştırmasına göre, özellikle iş hayatındaki istikrarsızlı̆̆ın yüksek seviyede stresi meydana getirdiği ve yaşam niteliğini azalttığı, iş ve özel yaşamı arasındaki dengeyi kurabilen kişilerin daha az stres seviyesine sahip oldukları saptanmıştır.

Seferov'un (2018) yapmış olduğu araştırmada kişinin algılanan örgütsel stres seviyesinin iş yaşam dengesizliğine yol açabileceği ve iş yaşam dengesizliğinin de örgütsel stresin artmasına neden olacağı sonucuna ulaşılmış ve algılanan stres ile iş-yaşam dengesi arasındaki ilişkinin anlamlı ve negatif yönde olduğu saptanmıştır. Tabak'ın (2019) yaptığı çalışma sonucunda, iş-yaşam dengesi ve stres arasında anlamlı bir ilişki olduğu belirtilmiş, iş yaşam dengesinin stres düzeyini negatif yönde etkilediği sonucuna varılmıştır.

Yapılan araştırmalar incelendiğinde stres ile iş yaşam dengesi arasında negatif bir etkinin olduğu yönündedir ve çalışmalar birbirini destekler niteliktedir. İş-yaşam dengesizliğinden kaynaklı stres seviyesinin artması bireylerde üretkenliği azaltma, işe gelmeme, işte var olmama gibi durumlara neden olmakta bunlar da motivasyonun ve performansın olumsuz etkilenmesine sebebiyet vermektedir.

COVID-19 salgını, vaka ve ölüm sayılarının artması ile dünyada kriz haline gelmiştir. Bu kriz ortamında değişen çalışma koşulları ve belirsizliğinde etkisiyle çalışanlarda fiziksel ve psikolojik baskı oluşturup; çalışanlarda stres ve kaygı seviyesini arttırmış, COVID-19 bir tehdit unsuru olarak görüldüğü için de iş yaşam dengesi düzeylerinin değişmesi öngörülmektedir. Bireyler bu dönemde iş, aile ve özel yaşam üçgeni arasında yaşantısını devam ettirmekte ve birbiriyle bağlantılı bu üç faktörün meydana getirdiği stres kaynakları ile mücadelesini sürdürmek durumundadır.

\subsection{Stres ve Motivasyon İlişkisi}

İnsanların çalışma hayatını etkileyen birçok faktör bulunmaktadır. Bunların başında motivasyon ve stres faktörü yer almaktadır. Olumlu faktörler bireyleri olağandan daha çok çaba sarf ederek örgüte yarar sağlamaya teşvik ederken, olumsuz faktörler de çalışan bireylerin sağlayabilecekleri verimliliği düşürecektir. Bu sebeple olumlu unsurlardan biri motivasyondur ve bireyleri daha fazla çalışmaya teşvik etmektedir. Stres ise en tehlikeli olumsuz unsurlardan biridir. Stresin motivasyon üstünde negatif etkiler yarattığı ve örgütlerin bu konuda tedbir almasının, oluşabilecek olumsuz durumların azalması açısından önemli olduğu düşünülmektedir (Uludağ, 2019).

Motivasyon çalışan bireylerin, örgüt amaç ve hedefleri doğrultusunda istekli çalışması ve yüksek verim sağlayabilmesi için gerekli koşulların araştırılması ve meydana getirilmesi şeklinde ifade edilebilir. Motivasyonun literatürde yapılan tanımlamalarına bakıldığında üç temel unsur göze çarpmaktadır. Hareket eylemini başlatmak, davranışı yönlendirmek ve davranışı sürdürmek olarak belirtilen bu unsurlar motivasyonun temelini oluşturmaktadır (Saracel, vd., 2015). Stres kaynakları (bireysel ve örgütsel) ve tepkileri bireyden bireye nasıl farklılık gösteriyorsa motivasyon ve motivasyon farktörleri de aynı şekilde değişiklik göstermektedir.

Stres ve motivasyon arasında anlamlı, ters orantılı negatif ilişki bulunmaktadır. Uludağ (2019)'ın yapmış olduğu araştırmada iş stresinin arttıkça motivasyonun azalacağı sonucunu göstermektedir. Çalışan motivasyonu performans açısından örgütleri de olumlu ve olumsuz şekilde etkilemektedir. Stres altında yeterince motive olamamış çalışan; ortaya verimli bir ürün koyamayacak, işe tam olarak kendini veremeyecek, çalışma arkadaşları ile sağlıklı iletişim kuramayacaktır. İş hayatında motive olamayan çalışan bunu özel yaşamına da yansıtacak, stres düzeyi daha da artacaktır. Örgüt yöneticileri bu noktada hem işletmenin hem de çalışanın verimliliğini sağlayabilmek adına oluşan stresin neden kaynaklı olduğunu, bu kaynağı nasıl azaltabileceğini ve örgüt başarısı için önemli olan motivasyon faktörlerinin neler olduğunu iyi analiz etmeli, bunlar için gerekli çalışmalarla destek olmalıdır. Şirketlerde çalışan motivasyonunu yükseltecek uygulamalar yapılması çalışanların inanç ve değerlerini olumlu etkilemektedir. McDonald's firması tarafindan da sıkça kullanılan bu yöntem ile firma hem çalışanlarını teşvik ederken hem de reklamını yapmaktadır. McDonald's yılda iki kez şubeler arasında en iyi hamburger yapan eleman yarışması düzenleyerek kazananlar arasından 
Amerika'nın en iyi hamburger şefini seçip madalya ve ödüllerle kazananları desteklemektedir. Bu tarz çalışan etkinlikleri, bireylerin istedikleri başarıyı elde etmelerini destekleyen ödüllendirmelerdir (Avc1, 2019, )

Yaşadığımız COVID-19 salgını itibariyle de yaşam daha stresli hale gelmiştir. Süreçten kaynaklı olumsuz algılanan stres, kişinin tehlike oluşturan çevre koşullarına dair gösterdiği reaksiyon ve bu zorlu koşullarla baş edebilme mücadelesidir. Bireyler sürecin belirsizliğinden, bu durumla başa çıkamayacaklarını sanmalarından, yaşadıkları olumsuz olaylar ve problemler zincirinden sonra insan vücudunda birtakım fiziksel ve psikolojik etkiler oluşacak ardından savunma mekanizması devreye girecektir. Aslında olumsuz bir faktör olarak düşünülse de stres, motive eden tetikleyici bir unsurdur. Var olan COVID-19 salgınını bir tehdit olarak algılamazsak, bu tehdidi ortadan kaldırmak için tetikleyici bir faktörün olmayacağı düşünülmektedir.

\subsection{Tehdit ve İş Yaşam Dengesi}

Günümüzde rekabete dayalı, gelişen teknolojinin ve hızla değişen dinamiklerin var olduğu iş dünyasında yoğun çalışma temposu çalışan bireyleri etkilemektedir. Yoğun çalışma temposu ve şirketlerin uyguladığı çalışma modellerinin getirmiş olduğu zorluklar ve dezavantajlar, bireylerin özel, aile ve iş yaşamındaki dengeyi kurmalarında, var olan dengeyi ise ayakta tutmalarını zorlaştırmaktadır (Erşan vd., 2013). Yaşamı işten ibaret olmayan bireyler, mutlu olabilmek için sosyal ve aile yaşamlarına da gerekli zamanı ayırarak dengeyi kurmaya çalışmaktadır. Birey her ne kadar bu dengeyi kurmaya çalışsa da günümüz çalışma koşulları iş ve özel yaşam arasındaki sınırları tehdit edebilmektedir. Özellikle çalışma saatlerindeki düzensizlikler, evden/uzaktan çalışma modeli, rol belirsizliği ve çatışması, çok fazla veya daha az iş yükü, maaşın tatmin etmemesi, iş ortamından kaynaklı fiziki etkenler gibi birçok unsur, çalışan bireyler üzerinde negatif etkiye sebep olmakta ve sağlıklarını tehdit altına almaktadır (Korkmaz \& Erdoğan, 2014).

Tehdit, kişilerin ya da örgütlerin eylemleri ve kontrolleri dişında var olan ve onlardan bağımsız hareket eden tehlikeli durumları betimler. Bu açıdan tehdidin "dışarıdan gelen" bir niteliği olduğu söylenebilir. Tehdit olarak görülen nesne, soyut bir durumu değil, gerçek ve somut olarak tanımlanabilen bir tehlike durumunu ifade etmektedir (Elmas, 2013). Tehlikeli durum olan ifade edilen tehdidi, algı olarak da düşünebiliriz. Algı, kişiden kişiye değişiklik göstermekte olup; tehlikeyi arz eden tehditler karşısında kişinin vereceği tepkiyi de etkileyecektir (Korkmaz, 2017). Dolayısıyla bir tehdit durumunun tanımlanmasında, söz konusu durumun sebep olabileceği potansiyel etkinin ve bu etkinin doğurabileceği sonuçların "bilinebilmesi, tahmin edilebilmesi ve kontrol edilebilmesi" önemlidir (Elmas, 2013).

Demirbağ ve diğerleri (2016), yaptıkları çalışmada algılanan tehdit kaynaklarına ilişkin bulgulara göre, katılımcıların belirginleşen temel kaygılarının fiziksel yaşamlarını koruma ve sürdürme güdüsüyle ilgili olduğu söylenebilir. Diğer bir deyişle, katılımcıların gündemindeki birincil tehdit kaynaklarının onların fiziki varlıklarının devamına yönelen tehditler olduğu görülmektedir. $\mathrm{Bu}$ kaygılardan sonra katılımcılar ikinci sırada sosyopolitik ve sosyokültürel varlıklarına yönelen tehditlerden korkmaktadır. Diğer yandan, bunların dışında katılımcıların kaygılandığı çok sayıda başka korku kaynağının da olduğu görülmektedir; ancak bu korkuların genellikle tekil olarak yaşandığı ya da görece düşük oranlarda diğer insanlar tarafından paylaşıldığı anlaşılmaktadır (Demirbağ vd., 2016). Algılanan COVID-19 tehdidi ise bireylerde korku, kayg1 ve stres seviyesini artırarak bireylerin iş yaşam dengesi üzerinde etkiye sahip olacağ 1 öngörülmektedir.

\subsection{Tehdit ve Motivasyon İlişskisi}

Algı, insan zihninde yaşanan olay, olgu ve durumların içinden kavramları seçerek hatırladığı, anlam kazandırdığı ve öğrendiği bilişsel bir süreçtir (Cognifit Research, 2021). Bireyler gündelik yaşamda çok fazla bilgiye maruz kalmakta, gereğinden fazla bilgi kişinin kapasitesini zorlamaktadır. $\mathrm{Bu}$ sebeple kişi algilamak istediği bilgileri kendi süzgecinden geçirmesi, filtrelemesi gerekmektedir. Gerek duyduğumuz bu filtreleme bireyin beklentileri, tercihleri, tecrübeleri ve dikkati aracillğıyla yapılabilir. Artık neyi algılaması gerektiğinin farkında olan birey seçtiği uyarıcıları bir bütün haline getirip anlam kazandırır ve algı sürecini tamamlar. Tehdit, stres, adalet, eşitlik, liderlik, motivasyon vb. unsurlar birer algıdır. Motivasyon, bireyin arzu ve isteklerine ulaşmasına yardımcı olan içsel bir süreci ifade ederken; kişiyi harekete geçiren, duygusal, sosyal ve bilişsel süreci de içinde barındıran 
bir çeşit algı anlamına da gelebilir. Pandemi sürecinde değişen hayatlarımızın yanında algılarımızın da değişkenlik gösterebileceğini söylemek mümkün olacaktır. Bireylerin sosyal davranışları, kendileri için en uygun konumdan dünyayı, bulundukları çevreyi algılayış tarzına bağlı olarak şekillenmektedir. Sosyal bir varlık olan insanın, dünyayı algılayışı; ferdin fiziki ve sosyal çevresi, psikolojik ve fizyolojik yapıs1, amaç ve hedefleri, geçmişteki deneyimlerinin ürünüdür (Korkmaz, 2017).

Tuna ve Türkmendağ' 'n (2020) çalışmasına göre pandemi döneminde çalışan bireyler için en mühim konu izolasyon sağlayıp kendilerini güvenli hissedebilmeleridir. Bu sebeple ev sağlıklı bir ortam hissi oluşturduğu için evden çalışan bireylerin motivasyonu artmıştır. Ayrıca işletmelerin sağladığı bu uygulama, çalışanlar için işletme yöneticilerinin kendilerine verdiği değerin bir ölçütü olarak görülmektedir. Bunun yanı sıra pandemi döneminde birçok işletme çalışanlarını tam mesaili olarak ofiste çalıştırmaya devam etmiştir. Yapılan araştırmalar bu durumun çalışanların motivasyonunu olumsuz etkilediğini göstermektedir (Tuna \& Türkmendağ, 2020). İşyerinden çalışmaya devam eden çalışanların dış ortam ile daha çok temas halinde olması, bu durumdan kaynaklı bulaşma riskinin yüksek olması; algılanan COVID-19 tehdidinin ve stresinin artmasına neden olmaktadır. Yüksek seviye tehdit ve stres ise bireyde düşük motivasyona sebebiyet vermektedir. Sönmez (2020) hizmet sektöründe çalışan bireylerle yaptığı görüşmeler sonucunda, COVID-19 kaygısının, bireylerin iş taleplerini yerine getirmede zorlandığı, rutin iş yapmalarını azalttığı, düşük performansa neden olduğunu tespit etmiştir. COVID-19 riskinin yarattığı olumsuz duygulardan biri olan kaygının çalışanlarda iş doyumsuzluğu, artan iş kazaları, motivasyon kaybı, düşük verim ve performans ile neticelendirilebilmektedir (Sönmez, 2020).Tehdit sadece bireyleri değil aynı düzeyde işletmeleri de etkisi altına altmaktadır. İşletmelerinde tehdit ortamını gözardı etmeyip gerekli önlemleri alması bu noktada önem kazanacaktır.

Tehdit, yaşanan farklı süreçler ve farklı algılarla şekillenen, yaşam koşullarına göre değişiklik gösterebilen bir kavramdır. Bir tehdidin varlığ sokmaktadır. COVID-19 tüm dünyayı saran beklenmedik etkiler yaratan küresel bir tehdit haline gelmiş̧ir (Arslan \& Karagül, 2020). COVID-19 salgınının insanlar için tehdit ortamı oluşturmasından söz edilse de bu durumun bireyler için tehdit olarak algılandığı ve her birey için aynı algı seviyesine sahip olabileceğini söylemek pek mümkün değildir. Kaçınılmaz bireysel farklılıklarla bireyler psikolojik ve fiziksel olarak virüsten eşit derecede etkilenmeyeceklerdir. COVID-19 salgını bireylerin üzerinde birçok psikolojik hasar bırakabilmektedir. Salgının atlatıldığı düşünüldüğünde bile bireylerdeki ölüm kaygısı devam edecektir. Artan kaygı beraberinde hem salgın sırasında hem de sonrasında daha yüksek düzeyde strese neden olacağı düşünülmektedir.

COVID-19 salgını bir kriz ortamı olarak değerlendirilirse, sürecin meydana getirdiği riskler, bireylerde algılanan tehdit, kaygı düzeyinin artmasına neden olmakta ve paralel yönde stresi de etkilemektedir. Zincirleme algılar zedelenirse bu durumun motivasyonun düşmesine neden olacağ beklenmektedir.

\section{ARAŞTIRMA METODOLOJISİ}

\subsection{Araştırma Amaç ve Önemi}

COVID-19 salgını, küresel boyutta tüm insanlık üzerinde tıbbi açıdan yarattığı olumsuz etkilerinin yanında ekonomik, sosyolojik ve psikolojik sonuçlar meydana getirmiştir. Çalışmanın amacı, COVID-19 salgınına yönelik algılanan stres ile tehdidin, iş yaşam dengesi ve çalışanların motivasyonu üzerindeki etkilerini ortaya koymaktır. Çalışmayı diğer araştırmalardan ayıran nokta, daha öncesinde benzer nitelikte bir çalışmanın yapılmamış olmasıdır. Güncel yaklaşım ışığında bu çalışmanın literatüre katkı sağlaması açısından önemli olacağı düşünülmektedir.

\subsection{Araştırmanın Örneklemi ve Ana kütle (Evren)}

Araştırmada, ana kütlede yer alan her bir bireyin, tarafsız şekilde örnekleme dahil edildiği ve seçilme olasılıklarının eşit olduğu "basit tesadüfî örnekleme" yöntemi kullanılmıştır (Balc1, 2007). Araştırmanın evren sayısı hakkında bilgimizin olmaması ama homojen yapıda olmasında dolayı oran tahmini yöntemi ile örnekleme hesabı yapılmıştır. Bu yönteme yönelik formülasyon aşăğda yer almaktadır (Özdemir vd., 2015). 


$$
\mathrm{n}=\frac{p * q * Z \frac{\alpha}{2}}{d^{2}}=\frac{0,5 * 0,5 *(1,96)^{2}}{(0,05)^{2}}=\frac{441784}{1150,9579} \cong 384
$$

Yukarıdaki örneklem hesabına göre araştırmanın güvenirliği ve geçerliliği için en az 384 örnekleme gerek vardır. Bu kapsamda araştırma için 390 katılımcı ile Nisan-Haziran ayları arasında online anket tekniği kullanılarak veri elde edilmiştir.

n: Örneklem büyüklüğü

$Z_{\frac{\alpha}{2}}=0,05$ anlamlılık düzeyinde $\mathrm{Z}$ tablo değeri

d: duyarll11k

p*q: homojen yapıdaki kitle oranına ilişkin varyans

\subsection{Veri Toplama Yöntem ve Süreci}

Araştırmada yer alan veriler, Google Forms'ta tasarlanan online anket yöntemi kullanılarak elde edilmiştir. Bu çalışmada anket uygulaması için İstanbul Ticaret Üniversitesi Etik Kurulu'ndan 07/05/2021 tarihli ve E-65836846-044-209611sıra sayılı kararı ile izin alınmıştır. Veri toplama süreci 15 Nisan 2021 tarihinde başlayıp 13 Haziran 2021 tarihinde sonlandırılmıştır. Anket 390 çalışan tarafından cevaplanmıştır. Çalışmada 58 ifade içeren anket formu hazırlanmıştır. Beş bölümden oluşturulan anketin birinci bölümünde 12 ifadeden oluşan demografik sorulara yer verilmiştir. İkinci bölümde katılımcıların COVID-19 salgınında algılanan streslerini ölçmeye yönelik 5 ifade bulunmaktadır. Üçüncü bölümde katılımcılarda COVID-19 salgınında algılanan tehdit düzeylerini ölçmeye yönelik 3 ifade bulunmaktadır. Dördüncü bölümde çalışanların iş yaşam dengesini ölçmek için hazırlanan 20 ifade bulunmaktadır. Son olarak beşinci bölümde ise, çalışanların motivasyon düzeylerini ölçmeye yönelik 18 ifade yer almaktadır.

Algılanan Stres Ölçeği, Marteau ve Berker'in (1992) çalışmasından uyarlanmıştır. Ölçek 5 ifadeden oluşmaktadır. Algılanan Tehdit Ölçeği; Yang (2012) ve Lin ve Bautista'nın (2016) çalışmasından uyarlanmıştır. Ölçek 3 ifadeden oluşmaktadır. İş Yaşam Dengesi Ölçeği; Apaydın'ın (2011) çalışmasından alınmıştır. Ölçek 20 ifadeden oluşmakta ve 4 alt boyutu bulunmaktadır. $\mathrm{Bu}$ boyutlar; yaşamı ihmal etme, yaşamın işten ibaret olması, iş-yaşam uyumu ve kendine zaman ayırma şeklindedir. Motivasyon Ölçeği; Köroğlu'nun (2011) çalışmasından alınmıştır. Motivasyon Ölçeği 18 ifadeden oluşmakta ve 3 alt boyutu bulunmaktadır. Bu boyutlar; ekonomik motive araçları, psikososyal motive araçları ve yönetsel motive araçları şeklindedir.

Kullanılan 4 ölçeğin yanıt kategorisi 1'den 5'e kadar uzanan 5'li likert yapıda derecelendirilmiştir. Derecelendirmeler, 1-5 aralığında (1-Hiç katılmıyorum, 5-Tamamen katılıyorum) şeklinde puanlandırılmıştır.

\subsection{Araştırmanın Modeli ve Hipotezleri}

Şekil 1: Araştırma Modeli

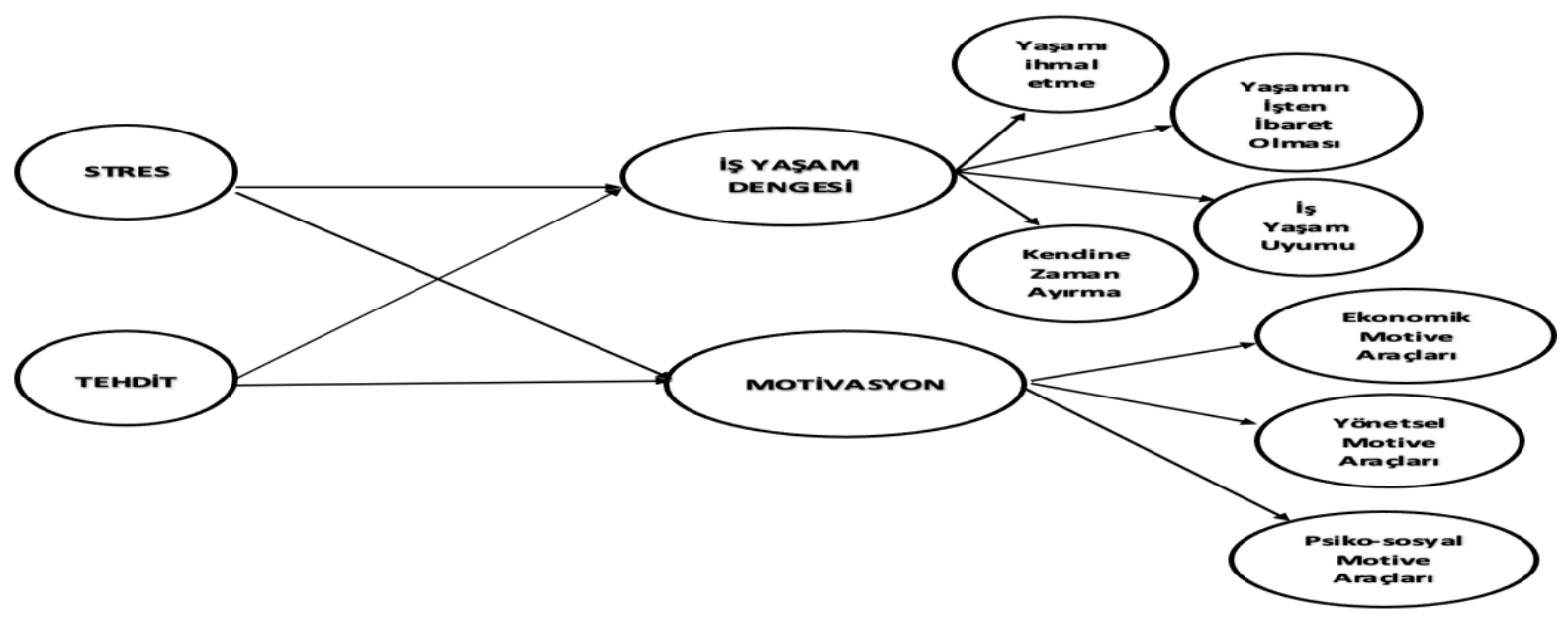




\subsubsection{Araștırmanın hipotezleri}

Literatürdeki bilgiler kapsamında aşağıdaki hipotezler oluşturulmuştur.

$\mathrm{H}_{1}$ : COVID-19'da algılanan stresin yaşamı ihmal etme üzerinde etkisi vardır.

$\mathrm{H}_{2}$ : COVID-19'da algılanan tehdidin yaşamı ihmal etme üzerinde etkisi vardır.

$\mathrm{H}_{3}$ : COVID-19'da algılanan stresin yaşamın işten ibaret olması üzerinde etkisi vardır.

$\mathrm{H}_{4}$ : COVID-19'da algılanan tehdidin yaşamın işten ibaret olması üzerinde etkisi vardır.

$\mathrm{H}_{5}$ : COVID-19'da algılanan stresin iş yaşam uyumu boyutu üzerinde etkisi vardır.

$\mathrm{H}_{6}$ : COVID-19'da algılanan tehdidin iş yaşam uyumu boyutu üzerinde etkisi vardır.

$\mathrm{H}_{7}$ : COVID-19'da algılanan stresin kendine zaman ayırma üzerinde etkisi vardır.

$\mathrm{H}_{8}$ : COVID-19'da algılanan tehdidin kendine zaman ayırma üzerinde etkisi vardır.

H9: COVID-19'da algılanan stresin psiko-sosyal motive araçları üzerinde etkisi vardır.

$\mathrm{H}_{10}$ : COVID-19'da algılanan tehdidin psiko-sosyal motive araçları üzerinde etkisi vardır.

$\mathrm{H}_{11}$ : COVID-19'da algılanan stresin ekonomik motive araçları üzerinde etkisi vardır.

$\mathrm{H}_{12}$ : COVID-19'da algılanan tehdidin ekonomik motive araçları üzerinde etkisi vardır.

$\mathrm{H}_{13}$ : COVID-19'da algılanan stresin yönetsel motive araçları üzerinde etkisi vardır.

H14: COVID-19'da algılanan tehdidin yönetsel motive araçları üzerinde etkisi vardır.

\subsection{Veri Analizi}

Elde edilen verilerin analizinde SPSS 22.0 ve LISREL 8.7 İstatistik paket programları kullanılmıştır. Katılımcıların demografik özelliklerine ilişkin değişkenler için frekans analizi yapılmış ve betimsel olarak incelenmiştir. Ölçeklerin faktör yapılarının incelenmesi için açımlayıcı ve doğrusal faktör analizi kullanılmıştır. Çalışmada kullanılan ölçeklere ilişkin güvenirlik ve geçerlilik analizleri yapılmıştır. Analiz sonuçlarına göre bazı sorular çalışmadan çıkarılmıştır. 390 kişilik örneklem çapı ile yapılan çalışmada, ölçeklerin geçerlilik ve güvenirliliği sağlanmıştır. Ölçeklerin güvenirliğinin sağlanmasında Cronbach Alpha değerlerine yer verilmiştir. Ölçek geçerliği incelenmesinde de "AVE ve CR" geçerlilik değerleri kullanılmıştır. Değişkenler arasında ilişkinin incelenmesi için korelasyon analizi yapılmıştır. Ölçeklerin geçerliliği ve güvenirliği sağlandıktan sonra araştırma modelinde yer alan hipotezlerin test edilmesi için ise yapısal eşitlik modeli kullanılmıştır.

\subsection{Bulgular}

\subsubsection{Demografik özelliklere ilișkin frekans analizi ve betimsel istatistikler}

Tablo 1: Katılımcıların Demografik Özellikleri

\begin{tabular}{|c|c|c|c|c|c|c|c|}
\hline Değişkenler & & Frekans & Yüzde (\%) & Değișkenler & & Frekans & Yüzde (\%) \\
\hline \multirow{3}{*}{ Cinsiyetiniz } & Erkek & 148 & 37,9 & \multirow{6}{*}{$\begin{array}{l}\text { Bu şirkette kaç } \\
\text { yıldır } \\
\text { çalışıyorsunuz? }\end{array}$} & 1 y1ldan az & 119 & 30,5 \\
\hline & Kadın & 242 & 62,1 & & $1-5 \mathrm{y} 1 \mathrm{l}$ & 180 & 46,2 \\
\hline & Toplam & 390 & 100,0 & & $11-15 \mathrm{y} 1 \mathrm{l}$ & 25 & 6,4 \\
\hline \multirow{3}{*}{$\begin{array}{l}\text { Medeni } \\
\text { durumunuz }\end{array}$} & Bekâr & 275 & 70,5 & & 16 y1l ve üstü & 20 & 5,1 \\
\hline & Evli & 115 & 29,5 & & $6-10$ y1l & 46 & 11,8 \\
\hline & Toplam & 390 & 100,0 & & Toplam & 390 & 100,0 \\
\hline \multirow{6}{*}{$\begin{array}{l}\text { Eğitim } \\
\text { düzeyiniz }\end{array}$} & Doktora & 16 & 4,1 & \multirow{3}{*}{$\begin{array}{l}\text { Fazla mesai } \\
\text { yapıyor } \\
\text { musunuz? }\end{array}$} & Evet & 205 & 52,6 \\
\hline & Lisans & 225 & 57,7 & & Hayır & 185 & 47,4 \\
\hline & Lise & 23 & 5,9 & & Toplam & 390 & 100,0 \\
\hline & Ön lisans & 25 & 6,4 & \multirow{3}{*}{$\begin{array}{l}\text { Fırsatınız olsa iş } \\
\text { değiştirmeyi } \\
\text { düşünür } \\
\text { müsünüz? }\end{array}$} & Evet & 204 & 52,3 \\
\hline & Yüksek Lisans & 101 & 25,9 & & Hayır & 186 & 47,7 \\
\hline & Toplam & 390 & 100,0 & & Toplam & 390 & 100,0 \\
\hline
\end{tabular}


Tablo 1 (Devamı): Katılımcıların Demografik Özellikleri

\begin{tabular}{|c|c|c|c|c|c|c|c|}
\hline Değişkenler & & Frekans & Yüzde (\%) & Değişkenler & & Frekans & Yüzde (\%) \\
\hline \multirow{3}{*}{$\begin{array}{l}\text { Çalıștığınız } \\
\text { sektör }\end{array}$} & Kamu & 97 & 24,9 & \multirow{6}{*}{$\begin{array}{l}\text { Yaşama şekliniz } \\
\text { nedir? }\end{array}$} & Ailemle & 209 & 53,6 \\
\hline & Özel & 293 & 75,1 & & Arkadaşımla & 22 & 5,6 \\
\hline & Toplam & 390 & 100,0 & & Diğer & 6 & 1,5 \\
\hline \multirow{4}{*}{$\begin{array}{l}\text { Çalışma } \\
\text { şekliniz }\end{array}$} & Evde & 106 & 27,2 & & Eşimle & 82 & 21,0 \\
\hline & $\begin{array}{l}\text { Hem evde hem } \\
\text { ofiste }\end{array}$ & 122 & 31,3 & & Yalnız & 71 & 18,2 \\
\hline & Ofiste & 162 & 41,5 & & Toplam & 390 & 100,0 \\
\hline & Toplam & 390 & 100,0 & \multirow{5}{*}{$\begin{array}{l}\text { Hiç COVID'e } \\
\text { yakalandınız mı? }\end{array}$} & $\begin{array}{l}\text { Evet, } \\
\text { yakalandım }\end{array}$ & 69 & 17,7 \\
\hline \multirow{7}{*}{$\begin{array}{l}\text { Çalıştığınız } \\
\text { şirketin } \\
\text { faaliyet alanı } \\
\text { nedir? }\end{array}$} & $\begin{array}{l}\text { Hizmet } \\
\text { İşletmesi }\end{array}$ & 303 & 77,7 & & $\begin{array}{l}\text { Hayır, } \\
\text { yakalanmadı } \\
\text { m }\end{array}$ & 317 & 81,3 \\
\hline & $\begin{array}{l}\text { Sanayi } \\
\text { İşletmesi }\end{array}$ & 45 & 11,5 & & $\begin{array}{l}\text { Şu an korona } \\
\text { virüslü } \\
\text { vakayım }\end{array}$ & 2 & 0,5 \\
\hline & $\begin{array}{l}\text { Ticaret } \\
\text { İşletmesi }\end{array}$ & 42 & 10,8 & & $\begin{array}{l}\text { Test } \\
\text { yaptırdım, } \\
\text { sonucunu } \\
\text { bekliyorum }\end{array}$ & 2 & 0,5 \\
\hline & \multirow{4}{*}{ Toplam } & \multirow{4}{*}{390} & \multirow{4}{*}{100,0} & & Toplam & 390 & 100,0 \\
\hline & & & & \multirow{3}{*}{$\begin{array}{l}\text { Ailenizde COVID } \\
\text { olan var mı? }\end{array}$} & Evet & 123 & 31,5 \\
\hline & & & & & Hayır & 267 & 68,5 \\
\hline & & & & & Toplam & 390 & 100,0 \\
\hline
\end{tabular}

Tablo 1'de katılımcıların demografik özelliklere ilişkin değiş̧kenler incelendiğinde, Cinsiyet; \%37,9 Erkek, \%62,1 Kadın, Medeni Durumu; \%70,5 Bekar, \%29,5 Evli, Eğitim düzeyi; \%5,9 Lise, \%6,4 Ön lisans, \%57,7 Lisans, \%25,9 Yüksek Lisans, \%4,1 Doktora, Çalıştığı Sektör; \%24,9 Kamu, \%75,1 Özel, Çalışma Sekli; \%27,2 Evde, \%31,3 Hem evde hem ofiste, \%41,5 ofiste, Çalıştığınız şirketin faaliyet alanı; \%77,7 Hizmet İşletmesi, \%11,5 Sanayi işletmesi, \%10,8 Ticaret İșletmesi olarak belirlenmiştir. Şirkette çalış1lan süre, \%30,5 1 yıldan az, \%46,2 1-5 y1l, \%6,4 11-15 y1l, \%5,1 16 y1l üstü, \%11,8 6-10 y1l arası olarak elde edilmiştir. \%52,6 Fazla mesai yaparken, \%47,4 normal mesai çalışma düzenindedir. \%52,3 Fırsatını bulsa işini değiştirmek isterken, \%47,7 iş değişikliği düşünmüyordur. Yaşama şekli; 53,6 ailesiyle, $\% 5,6$ arkadaşıyla, $\% 21,0$ eşiyle, $\% 18,2$ yalnız ve $\% 1,5$ diğer olarak belirlenmiştir. Araştırma esnasında katılımcıların koronavirüs durumu; \%17,7 evet yakalandım, \%81,3 hayır yakalanmadım, $\% 0,5$ şu an koronavirüs vakasıyım, $\% 0,5$ test yaptırdım, sonucu bekliyorum şeklindedir. Ayrıca, katılımcıların ailelerinde \%31,5 koronavirüs vakası varken, $\% 68,5$ 'inde koronavirüs vakası yoktur.

\subsection{2. Ölçeklere ilişkin açımlayıcı faktör analizi}

Faktör analizi, aralarında ilişki bulunan birden fazla değişkenin olduğu verilere ait ilişkilerin temel yapısını ortaya çıkartılarak, kavramlar arasındaki ilişkilerin daha basit olarak anlaşılmasına destek olmaktadır. Bulunan değişkenler, faktörler ve boyutlar olarak isimlendirilmektedir (Uygun, 2015: 100-102). Faktör analizinin uygunluğunun değerlendirilmesinde Bartlett küresellik testi ile Kaiser Mayer Olkin (KMO) testleri kullanılmaktadır. KMO test oranının; 0.90 üzeri elde edilmesi "mükemmel”, 0.80 “çok iyi”, 0.70 "iyi” 0.60 “orta” ve 0.60 '1n altı çıkması ise kabul edilemez düzeyde olduğunu ifade etmektedir. Bartlett test değerinin ise p önem düzeyinde anlamlı olması faktör analizi uygulanması için yeterli görülmektedir (Sharma, 1996; Kaiser, 1974) KMO ve Bartlett test değerlerinin uygun çıkması sonucu ele alınması gereken bir diğer parametre, ölçek ifadelerinin faktör yük değerleridir. Uygulamada, her bir ölçek ifadesi için faktör yüklerinin 0,30 ve üzerinde çıkması gerektiği belirtilmektedir. 0,50 ve üzerindeki değerlerin ise oldukça iyi olduğu kabul edilmektedir (Hair vd., 2009). Ayrıca analizlerde ölçek ifadelerinin ilgili boyutu ve ölçeği ne oranda açıklayabildiğini ifade eden varyans açıklama oranının \%40 ile \%60 arasında çıkması, varyans oranının yeterli olduğu şeklinde kabul edilmektedir (Tavşancıl, 2002). 
Tablo 2: Stres Ölçeğine İlişkin Açımlayıcı Faktör Analizi Sonuçları

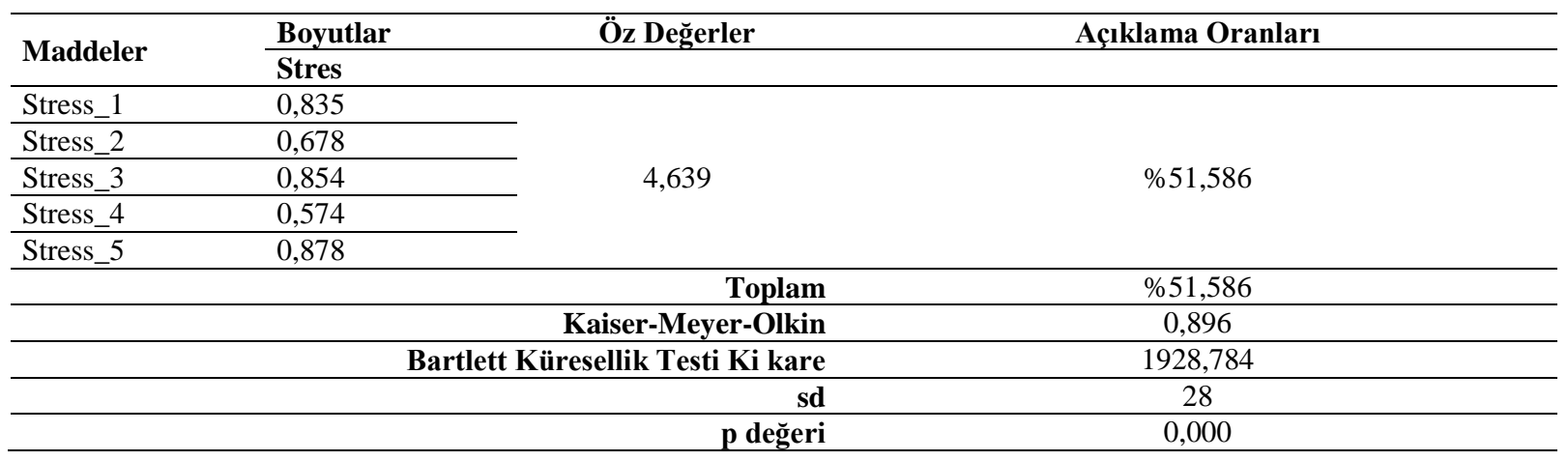

Tablo 2'deki sonuçlara göre; Stres ölçeği 5 farklı ifade olarak oluşturulmuştur. Faktör analizi sonucunda faktör ağırlı̆̆ 0,40 'ın üzerinde ve iyi ayrılmasından dolayı herhangi bir ifade araştırmadan çıkarılmamıştır. İlgili maddeler üzerinden incelenen 5 maddelik Stres ölçeği tek faktör olarak elde edilmiş ve KMO test değeri ile Bartlett test değerinin uygun olduğu sonucuna ulaşılmıştır. Faktörün toplam varyansı açıklama oranı $\% 51,586$ oranında elde edilmiştir.

Tablo 3: Tehdit Ölçeğine İlişkin Açımlayıcı Faktör Analizi Sonuçları

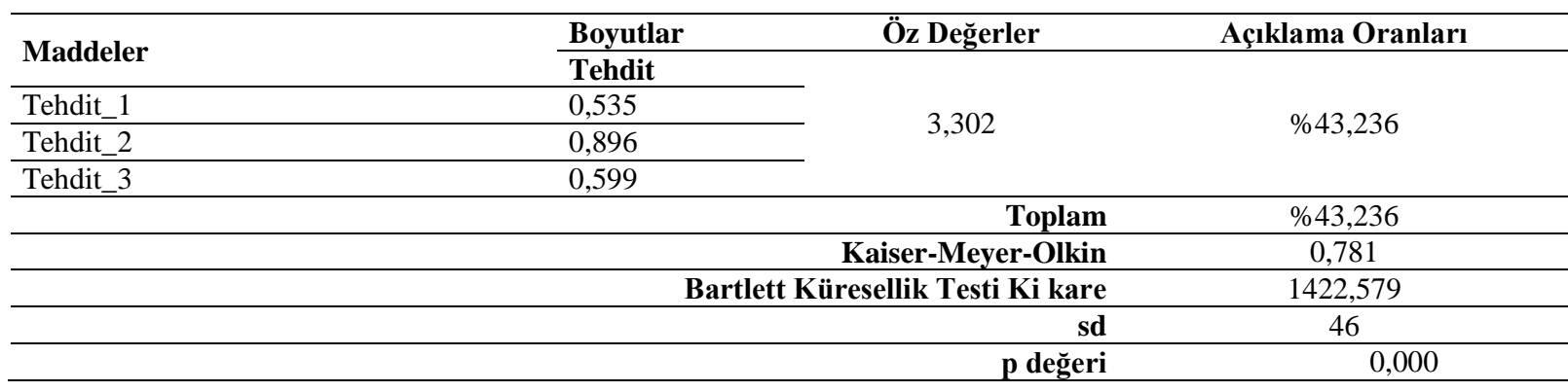

Tablo 3'teki sonuçlara göre; Tehdit ölçeği 3 farklı ifade olarak oluşturulmuştur. Faktör analizi sonucunda faktör ağırlı̆̆ 0,40 'ın üzerinde ve iyi ayrılmasından dolayı herhangi bir ifade araştırmadan çıkarılmamıştır. İlgili maddeler üzerinden incelenen 3 maddelik Tehdit ölçeği tek faktör olarak elde edilmiştir. KMO ve Bartlett test sonuçlarının uygun olduğu tespit edilmiş, faktörün toplam varyansı açıklama oranı \%43,236 oranında elde edilmiştir.

Tablo 4: İş-Yaşam Dengesi Ölçeğine İliş̧kin Açımlayıcı Faktör Analizi Sonuçları

\begin{tabular}{|c|c|c|c|c|c|c|}
\hline \multirow[b]{2}{*}{ Maddeler } & \multicolumn{4}{|c|}{ Alt Boyutlar } & Öz Değerler & $\begin{array}{c}\text { Açıklama } \\
\text { Oranları }\end{array}$ \\
\hline & $\begin{array}{c}\text { İş yaşam } \\
\text { Uyumu } \\
\text { Boyutu }\end{array}$ & $\begin{array}{l}\text { Yaşam İhmal } \\
\text { Etme }\end{array}$ & $\begin{array}{c}\text { Kendine Zaman } \\
\text { Ayırma }\end{array}$ & $\begin{array}{l}\text { Yaşamın İşten } \\
\text { İbaret OIması }\end{array}$ & \multirow{5}{*}{5,345} & \multirow{5}{*}{$\% 19,475$} \\
\hline Is_denge_1 & & 0,671 & & & & \\
\hline Is_denge_2 & & 0,793 & & & & \\
\hline Is_denge_4 & & 0,433 & & & & \\
\hline Is_denge_5 & & 0,522 & & & & \\
\hline Is_denge_14 & & & & 0,742 & \multirow{2}{*}{2,286} & \multirow{2}{*}{$\% 11,937$} \\
\hline Is_denge_15 & & & & 0,629 & & \\
\hline Is_denge_6 & 0,683 & & & & \multirow{6}{*}{1,239} & \multirow{6}{*}{$\% 11,189$} \\
\hline Is_denge_7 & 0,646 & & & & & \\
\hline Is_denge_8 & 0,724 & & & & & \\
\hline Is_denge_9 & 0,692 & & & & & \\
\hline Is_denge_17 & 0,633 & & & & & \\
\hline Is_denge_19 & 0,700 & & & & & \\
\hline Is_denge_12 & & & 0,686 & & \multirow{4}{*}{1,056} & \multirow{4}{*}{$\% 7,395$} \\
\hline Is_denge_13 & & & 0,552 & & & \\
\hline Is_denge_18 & & & 0,487 & & & \\
\hline Is_denge_20 & & & 0,526 & & & \\
\hline
\end{tabular}


Tablo 4 (Devamı): İş-Yaşam Dengesi Ölçeğine İlişkin Açımlayıcı Faktör Analizi Sonuçları

\begin{tabular}{rrr}
\hline & Toplam & $\% 49,995$ \\
\hline Kaiser-Meyer-Olkin & 0,868 \\
\hline Sd & Bartlett Küresellik Testi Ki kare & 2299,724 \\
\hline p değeri & 120 \\
\hline
\end{tabular}

Tablo 4'teki sonuçlara göre; iş-yaşam dengesi ölçeği 20 farklı ifade ve 4 alt boyuttan oluşmaktadır. Gerçekleştirilen faktör analizi sonucunda faktör yükü 0,40'ın altında olan, "Is_denge_10", Is_denge_11" "Is_denge_3" ve "Is_denge_16" ifadeleri araştırmadan çıkartılmıştır. Geriye kalan 16 madde üzerinden tekrarlanan faktör analizi sonucunda KMO ve Bartlett test sonuçlarının kabul edilir olduğu ve yine 4 faktör oluştuğu belirlenmiştir. 4 faktörün toplam varyansı açıklama oranı \% 49,995 oranında elde edilmiştir.

Tablo 5: Motivasyon Ölçeğine İlişkin Açımlayıcı Faktör Analizi Sonuçları

\begin{tabular}{|c|c|c|c|c|c|}
\hline \multirow[b]{2}{*}{ Maddeler } & \multicolumn{3}{|c|}{ Alt Boyutlar } & \multirow{2}{*}{$\begin{array}{c}\text { Öz } \\
\text { değerler }\end{array}$} & \multirow[b]{2}{*}{$\begin{array}{c}\text { Açıklama } \\
\text { Oranları }\end{array}$} \\
\hline & $\begin{array}{c}\text { Yönetsel Motive } \\
\text { Araçları }\end{array}$ & Ekonomi-Motive Araçları & $\begin{array}{c}\text { Psiko-Sosyal Motive } \\
\text { Araçları }\end{array}$ & & \\
\hline Mot_1 & & & 0,631 & \multirow{2}{*}{5,031} & \multirow{2}{*}{$\% 20,951$} \\
\hline Mot_2 & & & 0,653 & & \\
\hline Mot_4 & 0,690 & & & \multirow{5}{*}{1,434} & \multirow{5}{*}{$\% 19,807$} \\
\hline Mot_5 & 0,578 & & & & \\
\hline Mot_6 & 0,731 & & & & \\
\hline Mot_7 & 0,649 & & & & \\
\hline Mot_8 & 0,361 & & & & \\
\hline Mot_14 & & 0,700 & & \multirow{5}{*}{1,022} & \multirow{5}{*}{$\% 9,387$} \\
\hline Mot_15 & & 0,576 & & & \\
\hline Mot_16 & & 0,483 & & & \\
\hline Mot_17 & & 0,640 & & & \\
\hline Mot_18 & & 0,627 & & & \\
\hline & & & & Toplam & $\% 50,146$ \\
\hline & & & Kaiser- & yer-Olkin & 0,885 \\
\hline & & & Bartlett Küresellik & ti Ki kare & 1766,371 \\
\hline & & & & sd & 66 \\
\hline & & & & p değeri & 0,000 \\
\hline
\end{tabular}

Tablo 5'teki sonuçlara göre; Motivasyon ölçeği 18 farklı ifade ve 3 alt boyuttan oluşmaktadır. Gerçekleștirilen faktör analizi sonucunda faktör yükleri 0,40'ın altında olan, "Mot_3", "Mot 9" "Mot_10", "Mot_11", "Mot_12" ve "Mot_13" ifadeleri araştırmadan çıkartılmıştır. Geriye kalan 12 ölçek ifadesi üzerinden tekrarlanan faktör analizi sonucunda $\mathrm{KMO}$ ve Bartlett test değerlerinin uygun olarak kabul edildiği sonucuna varılmıştır. 3 faktörün toplam varyansı açıklama oranı \%50,146 oranında elde edilmiştir.

\subsection{3. Ölçeklere ilişkin doğrulayıcı faktör analizi ve DFA modeli uyum indeksleri}

Doğrulayıcı faktör analizi, açımlayıcı faktör analizi sonucu oluşan ölçek faktör yapılarının, geçerlilik analizleri temelinde doğrulanması ve geçerliliklerinin araştırılması amacıyla yapılmaktadır. Doğrulayıcı faktör analizi ile birlikte faktör yapılarının güvenilirliğini incelemek amacıyla Cronbach alfa değerleri de hesaplanmaktadır.

Güvenilirlik, bir ölçme aracının aynı şartlar altında yenilenen ölçümlerde elde edilen değerlerin kararlılı̆̆ını ifade etmektedir. Güvenilir olmayan bir ölçek kullanışsızdır ve Cronbach (1951) tarafından geliştirilen Alfa Katsayısı Yöntemi ile değerlendirilmektedir. Cronbach Alfa Değeri doğruyanlış seklinde puanlanamayan maddelerin 1-3, 1-4, 1-5 gibi puanlandığında kullanılan, iç tutarlılığı ölçen bir tahmin yöntemidir (Ercan \& Kan, 2004). Cronbach alfa katsayının genellikle 0,70 ve üzerinde tercih edilmesi önerilerken, 0,60'a kadar tolere edilmesi bazı yazarlar tarafindan uygun görülmüştür (Hair vd., 2009).

Geçerliliğin incelenmesinde birleşik geçerlilik ve benzeşim geçerliliği kullanılmaktadır. Birleşik güvenilirlik (CR) değerleri DFA'dan hesaplanan faktör yüklerinden hesaplanmaktadır. CR $\geq .70$ olduğunda birleşik güvenirlik koşulunun sağlandığı kabul edilmektedir (Raykov, 1997; Hair 
vd., 2009). Benzeşim geçerliliğinin göstergesi ise açılanan ortalama varyans (AVE) değeridir. Benzeşme geçerliliğinin teyit edilebilmesi için açıklanan ortalama varyansın (AVE $\geq 0.50$ ) olması gereklidir (Fornell \& Larcker, 1981).

Tablo 6: Stres Ölçeğine İlişkin Doğrulayıcı Faktör Analizi Sonuçları

\begin{tabular}{|c|c|c|c|c|c|c|c|c|c|c|}
\hline Alt boyutlar & Maddeler & B & Standardize B & Standart Hata & $\mathbf{t}$ & p & $\mathbf{R}^{2}$ & AVE & $\mathbf{C R}$ & $\begin{array}{c}\text { Cronbach's } \\
\text { Alpha }\end{array}$ \\
\hline \multirow{5}{*}{ Stres } & Stress_1 & 1,78 & 0,92 & 0,028 & 64,47 & $0,000 * *$ & 0,85 & \multirow{5}{*}{0,742} & \multirow{5}{*}{0,934} & \multirow{5}{*}{0,904} \\
\hline & Stress_2 & 1,67 & 0,79 & 0,060 & 27,75 & $0,000 * *$ & 0,63 & & & \\
\hline & Stress_3 & 1,70 & 0,92 & 0,034 & 50,44 & $0,000 * *$ & 0,84 & & & \\
\hline & Stress_4 & 1,19 & 0,69 & 0,064 & 18,63 & $0,000 * *$ & 0,48 & & & \\
\hline & Stress_5 & 1,58 & 0,96 & 0,015 & 106,83 & $0,000 * *$ & 0,92 & & & \\
\hline
\end{tabular}

Tablo 6'daki değerler incelendiğinde; Stres ölçeği için ölçek faktör yüklerini ifade eden standardize beta katsayılarının 0,40'ın üzerinde olması ve tüm değerlerin p önem düzeyinde anlamlı çıkması ( $p<0,001)$ faktör yapılarının doğrulandığını, Cronbach alfa güvenilirlik değerinin, AVE benzeşim geçerliliğinin ve CR birleşim geçerlilik değerlerinin olması gereken değerlerin üzerinde olması nedeniyle güvenilirliğin ve geçerliliğin sağlandığ 1 belirlenmiştir.

Tablo 7: Tehdit Ölçeğine İlişkin Doğrulayıcı Faktör Analizi Sonuçları

\begin{tabular}{llccccccccc}
\hline Alt boyutlar & Maddeler & $\mathbf{B}$ & Standardize B & Standart Hata & $\mathbf{t}$ & $\mathbf{p}$ & $\mathbf{R}^{2}$ & AVE & CR & $\begin{array}{c}\text { Cronbach's } \\
\text { Alpha }\end{array}$ \\
\hline \multirow{3}{*}{ Tehdit } & Tehdit_1 & 2,33 & 0,74 & 0,14 & 16,08 & $0,000^{* *}$ & 0,54 & & & \\
& Tehdit_2 & 2,42 & 0,87 & 0,098 & 24,71 & $0,000^{* *}$ & 0,76 & 0,658 & 0,852 & 0,758 \\
\cline { 2 - 12 } & Tehdit_3 & 2,28 & 0,82 & 0,067 & 19,23 & $0,000^{* *}$ & 0,67 & & & \\
\hline
\end{tabular}

CR; Composite Reliability, AVE; Average Variance Extracted; **p $<0,001, * \mathrm{p}<0,05$

Tablo 7'deki değerler incelendiğinde; Tehdit ölçeği için ölçek faktör yüklerini ifade eden standardize beta katsayılarının 0,40'ın üzerinde olması ve tüm değerlerin $\mathrm{p}$ önem düzeyinde anlamlı çıkması $(p<0,001)$ faktör yapılarının doğrulandığını, Cronbach alfa güvenilirlik değerinin, AVE benzeşim geçerliliğinin ve CR birleşim geçerlilik değerlerinin, olması gereken değerlerin üzerinde çıkması güvenilirliğin ve geçerliliğin sağlandığı kabul edilmiştir.

Tablo 8: İş-Yaşam Dengesi Ölçeğine İlişkin Doğrulayıcı Faktör Analizi Sonuçları

\begin{tabular}{|c|c|c|c|c|c|c|c|c|c|c|}
\hline $\begin{array}{l}\text { Alt } \\
\text { boyutlar }\end{array}$ & Maddeler & B & $\begin{array}{c}\text { Standardize } \\
\text { B } \\
\end{array}$ & $\begin{array}{c}\text { Standart } \\
\text { Hata }\end{array}$ & $\mathbf{t}$ & $\mathbf{p}$ & $\mathbf{R}^{2}$ & AVE & $\mathbf{C R}$ & $\begin{array}{c}\text { Cronbach's } \\
\text { Alpha }\end{array}$ \\
\hline \multirow{4}{*}{$\begin{array}{l}\text { Yaşamı } \\
\text { ihmal etme }\end{array}$} & Is_denge_1 & 1,53 & 0,80 & 0,065 & 23,48 & $0,000 * *$ & 0,64 & \multirow{4}{*}{0,577} & \multirow{4}{*}{0,843} & \multirow{4}{*}{0,805} \\
\hline & Is_denge_2 & 1,49 & 0,87 & 0,046 & 32,31 & $0,000 * *$ & 0,76 & & & \\
\hline & Is_denge_4 & 1,22 & 0,67 & 0,077 & 15,96 & $0,000 * *$ & 0,45 & & & \\
\hline & Is_denge_5 & 1,02 & 0,68 & 0,066 & 15,32 & $0,000 * *$ & 0,46 & & & \\
\hline \multirow{2}{*}{$\begin{array}{l}\text { Yaşamın } \\
\text { işten ibaret } \\
\text { olması }\end{array}$} & Is_denge_14 & 1,90 & 0,88 & 0,059 & 32,11 & $0,000 * *$ & 0,78 & \multirow{2}{*}{0,611} & \multirow{2}{*}{0,755} & \multirow{2}{*}{0,682} \\
\hline & Is_denge_15 & 1,29 & 0,67 & 0,096 & 13,38 & $0,000^{* *}$ & 0,45 & & & \\
\hline \multirow{6}{*}{$\begin{array}{l}\text { İş yaşam } \\
\text { uyumu }\end{array}$} & Is_denge_6 & 0,95 & 0,76 & 0,044 & 21,77 & $0,000 * *$ & 0,58 & \multirow{6}{*}{0,542} & \multirow{6}{*}{0,875} & \multirow{6}{*}{0,851} \\
\hline & Is_denge_7 & 1,04 & 0,67 & 0,072 & 14,32 & $0,000 * *$ & 0,44 & & & \\
\hline & Is_denge_8 & 1,65 & 0,85 & 0,050 & 32,69 & $0,000 * *$ & 0,72 & & & \\
\hline & Is_denge_9 & 0,89 & 0,74 & 0,047 & 19,13 & $0,000 * *$ & 0,55 & & & \\
\hline & Is_denge_17 & 0,98 & 0,65 & 0,067 & 14,72 & $0,000 * *$ & 0,42 & & & \\
\hline & Is_denge_19 & 0,88 & 0,73 & 0,049 & 18,01 & $0,000 * *$ & 0,54 & & & \\
\hline \multirow{4}{*}{$\begin{array}{l}\text { Kendine } \\
\text { Zaman } \\
\text { Ayırma }\end{array}$} & Is_denge_12 & 1,04 & 0,77 & 0,051 & 20,43 & $0,000 * *$ & 0,59 & \multirow{4}{*}{0,551} & \multirow{4}{*}{0,759} & \multirow{4}{*}{0,704} \\
\hline & Is_denge_13 & 1,62 & 0,75 & 0,079 & 20,42 & $0,000 * *$ & 0,56 & & & \\
\hline & Is_denge_18 & 0,99 & 0,69 & 0,064 & 15,54 & $0,000 * *$ & 0,46 & & & \\
\hline & Is_denge_20 & 0,79 & 0,42 & 0,10 & 7,77 & $0,000 * *$ & 0,17 & & & \\
\hline
\end{tabular}

Tablo 8'deki değerler incelendiğinde; İş Yaşam Dengesi ölçeği için ölçek faktör yüklerini ifade eden standardize beta katsayılarının 0,40'ın üzerinde olması ve tüm değerlerin $p$ önem düzeyinde anlamlı çıkması $(p<0,001)$ faktör yapılarının doğrulandığını, Cronbach alfa güvenilirlik değerlerinin, AVE benzeşim ve CR birleşim geçerlilik değerlerinin olması gereken değerlerin üzerinde olması nedeniyle güvenilirliğin ve geçerliliğin sağlandığı belirlenmiştir. Yaşamın işten ibaret olması boyutu 
için güvenilirlik değeri, Hair ve arkadaşlarının (2009), "bu değer 0,60'a kadar tolere edilebilir" görüşüne göre güvenilir olarak kabul edilmiştir.

Tablo 9: Motivasyon Ölçeğine İlişkin Doğrulayıcı Faktör Analizi Sonuçları

\begin{tabular}{|c|c|c|c|c|c|c|c|c|c|c|}
\hline $\begin{array}{l}\text { Alt } \\
\text { boyutlar }\end{array}$ & Maddeler & B & Standardize B & Standart Hata & $\mathbf{t}$ & $\mathbf{p}$ & $\mathbf{R}^{2}$ & AVE & CR & $\begin{array}{c}\text { Cronbach's } \\
\text { Alpha } \\
\end{array}$ \\
\hline \multirow{2}{*}{$\begin{array}{l}\text { Psiko- } \\
\text { Sosyal } \\
\text { Motive } \\
\text { Araçları } \\
\end{array}$} & Mot_1 & 1,29 & 0,68 & 0,15 & 8,60 & $0,000 * *$ & 0,46 & \multirow[b]{2}{*}{0,512} & \multirow[b]{2}{*}{0,771} & \multirow[b]{2}{*}{0,612} \\
\hline & Mot_2 & 1,52 & 0,75 & 0,17 & 9,14 & $0,000 * *$ & 0,56 & & & \\
\hline \multirow{5}{*}{$\begin{array}{l}\text { Ekonomik } \\
\text { Motive } \\
\text { Araçları }\end{array}$} & Mot_4 & 2,86 & 0,88 & 0,092 & 31,03 & $0,000 * *$ & 0,77 & \multirow{5}{*}{0,594} & \multirow{5}{*}{0,878} & \multirow{5}{*}{0,800} \\
\hline & Mot_5 & 2,79 & 0,81 & 0,12 & 23,10 & $0,000 * *$ & 0,65 & & & \\
\hline & Mot_6 & 2,96 & 0,79 & 0,13 & 22,72 & $0,000 * *$ & 0,63 & & & \\
\hline & Mot_7 & 2,24 & 0,77 & 0,10 & 22,06 & $0,000 * *$ & 0,59 & & & \\
\hline & Mot_8 & 1,15 & 0,57 & 0,10 & 11,10 & $0,000 * *$ & 0,33 & & & \\
\hline \multirow{5}{*}{$\begin{array}{l}\text { Yönetsel } \\
\text { Motive } \\
\text { Araçları }\end{array}$} & Mot_14 & 1,72 & 0,84 & 0,057 & 30,29 & $0,000 * *$ & 0,71 & \multirow{5}{*}{0,615} & \multirow{5}{*}{0,888} & \multirow{5}{*}{0,823} \\
\hline & Mot_15 & 1,21 & 0,66 & 0,080 & 15,13 & $0,000 * *$ & 0,43 & & & \\
\hline & Mot_16 & 1,48 & 0,78 & 0,064 & 23,08 & $0,000^{* *}$ & 0,60 & & & \\
\hline & Mot_17 & 2,89 & 0,84 & 0,094 & 30,82 & $0,000 * *$ & 0,71 & & & \\
\hline & Mot_18 & 1,68 & 0,79 & 0,065 & 25,93 & $0,000^{* *}$ & 0,63 & & & \\
\hline
\end{tabular}

Tablo 9'daki değerler incelendiğinde; Motivasyon ölçeği için, ölçek faktör yüklerini ifade eden standardize beta katsayılarını 0,40'ın üzerinde olması ve tüm değerlerin $\mathrm{p}$ önem düzeyinde anlamlı çıkması $(p<0,001)$ faktör yapılarının doğrulandığını, Cronbach alfa güvenilirlik değerlerinin, AVE benzeşim ve CR birleşim geçerlilik değerlerinin olması gereken değerlerin üzerinde olmas1 nedeniyle güvenilirliğin ve geçerliliğin sağlandığı sonucuna ulaşılmıştır. Psiko-sosyal motive araçları boyutu için güvenilirlik değeri, Hair ve arkadaşlarının (2009), "bu değer 0,60'a kadar tolere edilebilir" görüşüne göre güvenilir olarak kabul edilmiştir.

Doğrulayıcı faktör analizi sonuçlarında bakılması gereken önemli bir değer de uyum indeksidir. Literatürde en çok kullanılan uyum indeksi değerleri ve aralıkları aşağıda verilmiştir. $\mathrm{Bu}$ değerlerin kabul edilebilir ve iyi aralıkta olması, doğrulayıcı faktör analizinin ve oluşturulan modelin uygunluğunu göstermektedir (Jöreskog \& Sörbom, 1996; Schermelleh-Engel vd., 2003; Schumacker \& Lomax, 2004).

Tablo 10: Araştırma Modelinde Yer Alan Değişkenlere İlişkin DFA Uyum İndeksleri

\begin{tabular}{lcccccc}
\hline Uyum Ölçütleri & İyi Uyum* & $\begin{array}{c}\text { Kabul edilebilir } \\
\text { Uyum** }\end{array}$ & Stres & Tehdit & İş Yaşam Dengesi & Motivasyon \\
\hline GFI & $0 \leq \leq 2$ & $1-5$ & $2,08^{* *}$ & $2,79^{*}$ & $2,64^{*}$ & $3,11^{* *}$ \\
\hline CFI & $0,95 \leq \mathrm{GFI} \leq 1$ & $0,90 \leq \mathrm{GFI} \leq 0,95$ & $0,94^{* *}$ & $0,91^{* *}$ & 0,87 & 0,84 \\
\hline NNFI/TLI & $0,97 \leq \mathrm{CFI} \leq 1$ & $0,95 \leq \mathrm{CFI} \leq 0,97$ & $0,99^{*}$ & $0,98^{*}$ & $0,97^{*}$ & $0,98^{*}$ \\
\hline NFI & $0,97 \leq \mathrm{NNFI} \leq 1$ & $0,95 \leq \mathrm{NNFI} \leq 0,97$ & $0,99^{*}$ & $0,97^{*}$ & $0,97^{*}$ & $0,98^{*}$ \\
\hline RMR & $0,95 \leq \mathrm{NFI} \leq 1$ & $0,90 \leq \mathrm{NFI} \leq 0,95$ & $0,99^{*}$ & $0,98^{*}$ & $0,96^{*}$ & $0,97^{*}$ \\
\hline RMSEA & $0 \leq \mathrm{RMR} \leq 0,05$ & $0,05 \leq \mathrm{RMR} \leq 0,08$ & 0,23 & 0,33 & 0,20 & 0,41 \\
\hline
\end{tabular}

Kaynak: Jöreskog ve Sörbom, 1996; Schermelleh-Engel, Moosbrugger ve Müller, 2003; Schumacker ve Lomax, 2004

Tablo 10'daki Stres Ölçeğine ilişkin DFA Modeli Test Sonuçlarına göre; DFA'da Modelin uyum indeks değerleri, RMR $(0,23)$ değeri kötü uyuma sahipken, Chi-square/df(cmin/df) $(2,08))$, GFI $(0,94)$, CFI $(0,99)$, NNFI $(0,99)$, NFI $(0,99)$, RMSEA $(0,053)$ değerlerinin kabul edilir ve iyi uyum sınırları içinde yer aldığından dolayı DFA modelinin geçerli olduğu söylenebilir. Tehdit Ölçeğine ilişkin DFA Modeli Test Sonuçlarına göre; DFA'da Modelin uyum indeks değerleri, RMR $(0,23)$ değeri kötü uyuma sahipken, Chi-square/df(cmin/df) $(2,79))$, GFI $(0,91)$, CFI $(0,98)$, NNFI $(0,97)$, NFI $(0,98)$, RMSEA $(0,067)$ değerlerinin kabul edilir ve iyi uyum sınırları içinde yer aldığından dolayı DFA modelinin geçerli olduğu söylenebilir. İş-Yaşam Dengesi Ölçeğine ilişkin DFA Modeli Test Sonuçlarına göre; DFA'da Modelin uyum indeks değerleri, $\operatorname{GFI}(0,87), R M R(0,20)$ değerleri kötü uyuma sahipken, Chi-square/df(cmin/df) (2,64)), CFI (0,97), NNFI (0,97), NFI (0,96), RMSEA $(0,064)$ değerlerinin kabul edilir ve iyi uyum sınırları içinde yer aldığından dolayı DFA modelinin geçerli olduğu söylenebilir. Motivasyon Ölçeğine ilişkin DFA Modeli Test Sonuçlarına göre; DFA'da 
Modelin uyum indeks değerleri, GFI $(0,84), R M R(0,41)$ değerleri kötü uyuma sahipken, Chisquareldf(cmin/df) (3,11)), CFI (0,98), NNFI (0,98), NFI (0,97), RMSEA $(0,074)$ değerlerinin kabul edilir ve iyi uyum sınırları içinde yer aldığından dolayı DFA modelinin geçerli olduğu söylenebilir.

\subsubsection{Yapısal Eşitlik Modeli}

Şekil 2: Yapısal Eşitlik Modeli Yol Diyagramı

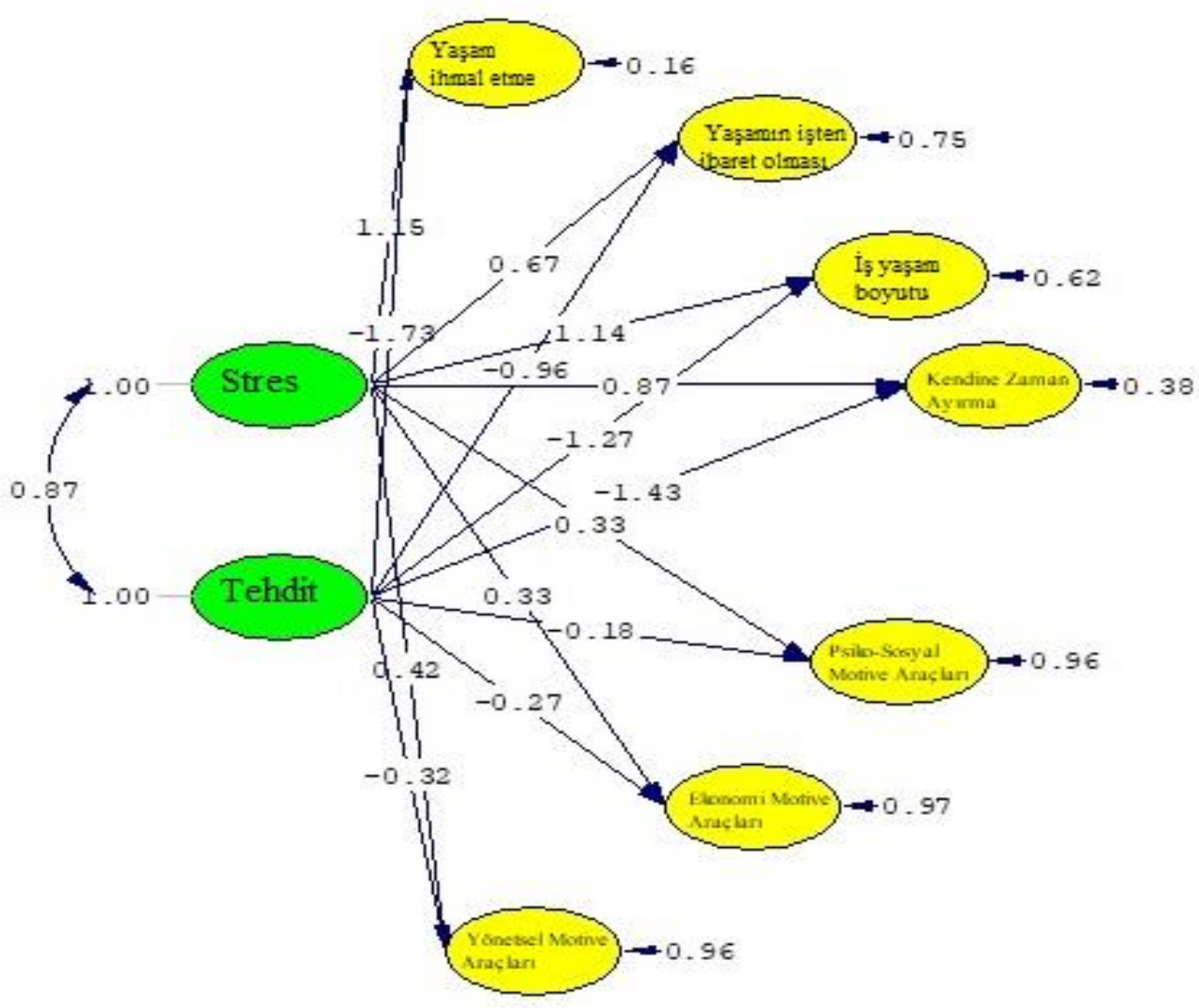

Tablo 11: Yapısal Eşitlik Modeli Sonuçları

\begin{tabular}{|c|c|c|c|c|c|c|}
\hline & B & Standardize B & $\begin{array}{c}\text { Standart } \\
\text { Hata }\end{array}$ & $\mathbf{t}$ & $\mathbf{p}$ & $\mathbf{R}^{2}$ \\
\hline Stres $\rightarrow$ Yaşamı ihmal etme & 1,15 & 1,15 & 0,26 & 4,45 & $0,000 * *$ & \multirow{2}{*}{0,84} \\
\hline Tehdit $\rightarrow$ Yaşamı ihmal etme & $-1,73$ & $-1,73$ & 0,24 & $-7,34$ & $0,000 * *$ & \\
\hline Stres $\rightarrow$ Yaşamın işten ibaret olması & 0,67 & 0,67 & 0,19 & 3,52 & $0,001 * *$ & \multirow{2}{*}{0,25} \\
\hline Tehdit $\rightarrow$ Yaşamın işten ibaret olması & $-0,96$ & $-0,96$ & 0,18 & $-5,49$ & $0,000 * *$ & \\
\hline Stres $\rightarrow$ İş yaşam uyumu & 1,14 & 1,14 & 0,22 & 5,25 & $0,000 * *$ & \multirow{2}{*}{0,38} \\
\hline Tehdit $\rightarrow$ İş yaşam uyumu & $-1,27$ & $-1,27$ & 0,20 & $-6,31$ & $0,000 * *$ & \\
\hline Stres $\rightarrow$ Kendine Zaman Ayırma & 0,87 & 0,87 & 0,25 & 3,48 & $0,001 * *$ & \multirow{2}{*}{0,62} \\
\hline Tehdit $\rightarrow$ Kendine Zaman Ayırma & $-1,42$ & $-1,43$ & 0,22 & $-6,45$ & $0,000 * *$ & \\
\hline Stres $\rightarrow$ Psiko-Sosyal Motive Araçları & 0,50 & 0,33 & 0,2 & 2,06 & $0,039 *$ & \multirow{2}{*}{0,035} \\
\hline Tehdit $\rightarrow$ Psiko-Sosyal Motive Araçları & $-0,29$ & $-0,18$ & 0,24 & $-1,20$ & 0,230 & \\
\hline Stres $\rightarrow$ Ekonomik Motive Araçları & 0,33 & 0,33 & 0,14 & 2,47 & $0,013 *$ & \multirow{2}{*}{0,027} \\
\hline Tehdit $\rightarrow$ Ekonomik Motive Araçları & $-0,27$ & $-0,27$ & 0,14 & $-1,94$ & 0,052 & \\
\hline Stres $\rightarrow$ Yönetsel Motive Araçları & 0,42 & 0,42 & 0,13 & 3,14 & $0,002 * *$ & \multirow{2}{*}{0,045} \\
\hline Tehdit $\rightarrow$ Yönetsel Motive Araçları & $-0,32$ & $-0,32$ & 0,14 & $-2,26$ & $0,023^{*}$ & \\
\hline
\end{tabular}

Tablo 11'de yer alan katsayılara ilişkin değerlendirmeler aşağıda yer almaktadır.

Yapısal eşitlik modeli yol analizi sonuçlarında standardize B (yol) katsayıları değerlendirilirken, bağımsız değişkenin bağımlı değişken üzerindeki göreli etkisini gösteren regresyon temelli katsayılar kullanılmaktadır. Örneğin, standardize yol katsayısının 2 çıkması, bağımsız 
değişkendeki 1 birimlik artışın, bağımlı değişken üzerinde 2 birimlik artış meydana getireceğini ifade etmektedir. Bu katsayıların anlamlılığına bakılmasında p önem değerlerine bakılmaktadır (Ayyıldız \& Cengiz, 2006:70).

COVID-19 stres ve algılanan tehdidinin, iş yaşam dengesi boyutlarından yaşamı ihmal etme üzerindeki etkisinin, istatistiksel olarak anlamlı olduğu belirlenmiştir(p<0,001). Bu durumda stres değişkenindeki bir birimlik değişim yaşamı ihmal etmede 1,15 birim bir artışa neden olurken, tehdit değişkenindeki bir birimlik değişim, yaşamı ihmal etmede 1,73 birim bir azalışa neden olmaktadır. $R^{2}=0,84$ olduğu için; stres ve tehdidin yaşamı ihmal etmeyi \%84 oranında açıkladığı belirlenmiş, $\mathbf{H}_{\mathbf{1}}$ ve $\mathbf{H}_{2}$ hipotezleri doğrulanmıştır.

COVID-19 stres ve tehdidinin yaşamın işten ibaret olması üzerindeki etkisinin, istatistiksel olarak anlamlı olduğu belirlenmiștir $(p<0,001)$. Bu durumda stres değișkenindeki bir birimlik değișim yaşamın işten ibaret olmasında 0,67 birim bir artışa neden olurken, tehdit değişkenindeki bir birimlik değişim, yaşamın işten ibaret olmasında 0,96 birim bir azalışa neden olmaktadır. $R^{2}=0,25$ olduğu için; stres ve tehdidin, yaşamın işten ibaret olması \%25 oranında açıkladığı belirlenmiş, $\mathbf{H}_{3}$ ve $\mathbf{H}_{4}$ hipotezleri doğrulanmıştır.

COVID-19 stres ve tehdidinin iş yaşam uyumu üzerindeki etkisinin, istatistiksel olarak anlamlı olduğu belirlenmiştir(p<0,001). Bu durumda stres değişkenindeki bir birimlik değişim iş yaşam uyumunda 1,14 birim bir artışa neden olurken, tehdit değişkenindeki bir birimlik değişim, İş yaşam uyumunda 1,27 oranında bir azalışa neden olmaktadır. $R^{2}=0,38$ olduğu için; stres ve tehdidin iş yaşam uyumunu $\% 38$ oranında açıkladığı belirlenmiş, $\mathbf{H}_{5}$ ve $\mathbf{H}_{6}$ hipotezleri doğrulanmıştır.

COVID-19 stres ve tehdidinin kendine zaman ayırma üzerinde etkisinin istatistiksel olarak anlamlı olduğu belirlenmiştir $(\mathrm{p}<0,001)$. Bu durumda stres değişkenindeki bir birimlik değişim kendine zaman ayırmada 0,87 birim bir artıșa neden olurken, tehdit değișkenindeki bir birimlik değişim, kendine zaman ayırmada 1,42 birim bir azalışa neden olmaktadır. $R^{2}=0,62$ olduğu için; stres ve tehdidin kendine zaman ayırma \%62 oranında açıkladığı belirlenmiş, $\mathbf{H}_{7}$ ve $\mathbf{H}_{\mathbf{8}}$ hipotezleri doğrulanmıştır.

COVID-19 stres ve tehdidinin psiko-sosyal motive araçları üzerindeki etkileri incelendiğinde, tehdidin psiko-sosyal motive araçları üzerinde etkisinin istatistiksel olarak anlamlı olmadığı belirlenmiştir $(p>0,05)$. Diğer taraftan, stresin psiko-sosyal motive araçları üzerinde etkisinin istatistiksel olarak anlamlı olduğu belirlenmiştir $(\mathrm{p}<0,05)$. Bu durumda stres değişkenindeki bir birimlik değişim psiko-sosyal motive araçlarında 0,50 birim bir artışa neden olmaktadır. $R^{2}=0,035$ olduğu için; stresin psiko-sosyal motive araçlarını \%3,5 oranında açıkladığ 1 belirlenmiş, $\mathbf{H}_{\mathbf{9}}$ hipotezleri doğrulanmış, $\mathbf{H}_{10}$ hipotezleri doğrulanmamıştır.

COVID-19 stres ve tehdidinin ekonomik motive araçları üzerindeki etkileri incelendiğinde, tehdidin ekonomik motive araçları üzerinde etkisinin istatistiksel olarak anlamlı olmadığı belirlenmiștir ( $>0,05)$. Diğer taraftan, stresin ekonomik motive araçları üzerinde etkisinin istatistiksel olarak anlamlı olduğu belirlenmiştir( $(\mathrm{p}<0,05)$. Bu durumda stres değişkenindeki bir birimlik değişim, ekonomik motive araçlarında 0,33 birim bir artışa neden olmaktadır. $R^{2}=0,027$ olduğu için; stresin ekonomik motive araçlarını \%2,7 oranında açıkladığı belirlenmiş, $\mathbf{H}_{11}$ hipotezleri doğrulanmış, $\mathbf{H}_{12}$ hipotezleri doğrulanmamıştır.

COVID-19 stres ve tehdidinin yönetsel motive araçları üzerinde etkisinin istatistiksel olarak anlamlı olduğu belirlenmiştir $(p<0,001 ; p<0,05)$. Bu durumda stres değişkenindeki bir birimlik değişim yönetsel motive araçlarında 0,42 birim bir artışa neden olurken, tehdit değişkenindeki bir birimlik değişim, yönetsel motive araçlarında 0,32 birim bir azalışa neden olmaktadır. $R^{2}=0,045$ olduğu için; stres ve tehdidin yönetsel motive araçları \%4,5 oranında açıkladığı belirlenmiş, $\mathbf{H}_{\mathbf{1 3}}$ ve $\mathbf{H}_{14}$ hipotezleri doğrulanmıştır.

\section{SONUC}

Çin'de Aralık 2019 tarihinde insanlarda ilk defa rastlanan, bu sebepten dolayı da ilk aşamada ne yapılacağı bilinemeyen COVİD-19 salgını, insan yaşamını ve alışkanlıklarının bir anda yeniden biçimlendirilmesini zorunlu kılmıştır. Dünya karar alıcıları ve hükümetler salgının yayılması ve 
bulaşmasını azaltmak amacıyla çeşitli önlemler almışlardır. Başlangıçta, insanların durumun ehemmiyetinin farkında olmamaları nedeniyle, kurallara sıkı bir şekilde uyulmaması durumunda hükümetler cezai yaptırımlar uygulamaya başlamıştır. Salgının giderek artması ve enfekte olan kişilerin durumlarının ağırlaşması ile hayatlarını kaybetmeleri, virüsün insan sağlığını ciddi anlamda tehdit etmesi ve bunun telafi edilemeyecek sonuçlara mâl olmasıyla durumun ciddiyetini açıkça ortaya koymaktadır. Salgının hem bireylerin kendilerine hem de sevdiklerine bulaşma ve ölme riskinin ortaya çıkması kişilerin strese girmelerine, ölüm korkularının oluşmasına ve endişelenmelerine neden olmuştur. Koronavirüs aslında sadece insan sağlığı için olumsuz etkiler oluşturmamış, aynı zamanda bireylerde psikolojik açıdan derin etkiler bırakmıştır. Sosyal izolasyonu sağlamak, güvende olabilmek için kişiler, kendilerini ve diğer insanları da korumak amacıyla karantinada daha çok evde vakit geçirmişlerdir. $\mathrm{Bu}$ süreçte evde geçirilen vakit, bireylerin sosyal yaşamdan uzaklaşmalarına, sevdikleriyle görüşmelerin yok denecek kadar azalmasına, fiziksel aktivitelerde bulunamamalarından kaynaklı kişilerin daha çok kendi içlerine dönmelerine neden olmuştur.

İnsan doğası gereği yaşamını tek başına devam ettirmesi güç olmakla birlikte sosyalleşmesi de yok sayılamayacak kadar önem ifade etmektedir. Bu sebeple bireylerin birbirleri ile sosyalleşmesi ve farkl1 aktivitelerde bulunması fizyolojik ve psikolojik açıdan önemli olacaktır. Değişen dünya düzeninde çalışma hayatı da yerini almıştır. İşletmeler çalışanların sağlığını riske atmamak için esnek/uzaktan çalışma düzenine geçiş sağlamıştır. İlk defa uzaktan çalışma sistemini uygulayacak şirketler ve çalışanlar başta bu duruma uyum sağlamakta güçlük çekmişlerdir. Var olan iş ve yaşam düzenleri bu uygulamayla birlikte ciddi değişimlere uğramıştır. Evden çalışan bireylerin hem iş hem de aile yaşamlarının aynı ortamın içinde olması, ev ortamının çalışma ortamına uygun olmayışı, evde yapılması gereken birden fazla işin olması ve kişinin hepsine eşit düzeyde yetişemiyor olması işyaşam dengesizliğine ortam hazırlamaktadır. Bireylerin işi ve özel yaşamı arasında gerekli dengeyi kuramaması ya da var olan bir dengenin, sürecinde etkisiyle bozulması beraberinde bireylerin stres düzeyleri de artacaktır. İki alanda çok fazla role sahip olunması ve aynı zamanda rol belirsizliğinin oluşması iş ve özel yaşam arasında çatışmaya sebebiyet vermektedir. Yaşanan rol belirsizliği, rol çatışması kişileri stres altına alarak iş ve aile ortamlarında ister istemez yansımaları görülmektedir. Stresli, mutsuz, huzursuz bireyler çalışma hayatında işe gelmeme isteği, performans düşüklüğü, düşük motivasyon ve ilerleyen dönemlerde belki de işten ayrılma niyetini meydana getirebileceği düşünülmektedir.

Çalışmanın bulguları sonucunda algılanan stres ve tehdidin, çalışanların iş yaşam dengesi ve motivasyonunu anlamlı bir şekilde etkilediği saptanmıştır. Stresin iş yaşam dengesi ve motivasyon alt boyutlarının tümü üzerinde pozitif yönlü etkisi olduğu, tehdidin ise iş yaşam dengesi alt boyutlarının tümü üzerinde negatif, motivasyon alt boyutlarında ise sadece yönetsel motive araçları üzerinde negatif yönlü etkisi olduğu sonucuna ulaşılmıştır. Stresin iş yaşam dengesi boyutlarından en çok yaşamı ihmal etme üzerinde, motivasyon alt boyutlarından ise en çok psiko-sosyal motive araçları üzerinde etkisi vardır. Tehdidin ise iş yaşam dengesi alt boyutlarından en çok yaşamı ihmal etme üzerinde etkisi olduğu belirlenmiştir. Analiz sonuçlarına göre H10 ve H12 hipotezleri doğrulanmamıştır. Tehdidin motivasyon alt boyutları olan psiko-sosyal motive araçları ve ekonomik motive araçları üzerinde etkisinin olmadığ 1 belirlenmiştir.

Uludağ (2019), stresin motivasyon üzerinde olumsuz etkiler yarattığını belirtirken, yapılan çalışma sonucunda stresin motivasyona pozitif yönlü bir etkisinin olduğu ortaya konulmuştur. Stres ne kadar olumsuz, negatif bir unsur olarak düşünülse de pozitif etkisi de bulunmaktadır. Kısaca stres seviyesi arttıkça motivasyonda artmaktadır. Özellikle stresin en çok motivasyonun alt boyutu olan psiko-sosyal motive aracı değişkeni üzerinde etkisi var olduğu tespit edilmiştir. Bu bağlamda stresin içsel motivasyonu arttırıcı özelliği olduğu söylenebilir. Saracel ve diğerlerinin (2015) yaptığı araştırma sonucunda örgütsel stresinin iş motivasyonu üzerinde pozitif etkisi olduğu belirtilmiş, buradan hareketle bu iki çalışmanın birbirini desteklediği, kısmen de olsa paralellik gösterdiği söylenebilir. Literatür incelendiğinde, stresin iş yaşam dengesi üzerinde negatif etkisinin çoğunluklu olduğu gözlemlenmiştir (Özdemir, 2017; Yavuz \& Doğan, 2018; Seferov, 2018; Tabak, 2019). Yapılan çalışmalar dikkate alındığında stres ile iş yaşam dengesi arasında negatif ilişkinin olması beklenirken, diğer çalışmalardan farklı olarak stresin iş yaşam dengesi üzerinde pozitif etkisinin olduğu sonucuna varılmıştır. İş stresi iş yaşam dengesi üzerinde negatif etki bırakırken COVID-19 döneminin vermiş 
olduğu stres, farklı çalışma şekillerinin de ortaya çıkmasıyla birlikte bu durumun literatüre göre farklılık gösterdiğini ortaya çıkarmıştır. Pandemi döneminde evden çalışan bireylerin hem iş hem de ev yaşantılarının bir arada olması, ev işleri ile mesleki işlerinin iç içe geçmesine neden olurken diğer taraftan fazla iş yükü ve bütün işlere yetişme telaşı bireylerin stres seviyelerini arttırmıştır. COVID-19 dönemiyle birlikte yaşanan stresin artmasıyla iş yaşam dengesinin de artıyor olması, çalışan bireylerin stres ile başa çıkabildiklerini ve bunun olumlu stres olarak algılandığını göstermektedir. Stresin artmasının motivasyonu da arttırıyor olması bireylerin iş yaşam dengesinin sağlanmasında dengeleyici olduğunu düşündürtmektedir. Bir yandan ise salgının bireylerde yarattığı tehdit algısının iş yaşam dengesini negatif yönde etkilediği sonucuna ulaşılmıştır. Bu sonuçlara göre, COVID-19 sürecinde, bireylerin hem işlerini hem sağlıklarını tehlike altında hissetmeleri korku, endişe ve kaygılanmalarına neden olmuş, bu durumun iş ve özel yaşam arasındaki dengeyi kurmalarını güçleştirdiği düşünülmektedir.

Araştırma pandemi döneminde yapılmıştır, boylamsal çalışma pandemi bittikten sonra da yapılabilir; aşı öncesi ve sonrasında da değerlendirilebilir. Korku, örgütsel bağlılık, işte var olmama, işten ayrılma niyeti, kaygı, tükenmişlik, vb. değişkenler kullanılarak çalışma tekrarlanabilir.

Etik Beyan: Bu çalı̧̧mada anket uygulaması için İstanbul Ticaret Üniversitesi Etik Kurulu'ndan 07/05/2021 tarihli ve E-65836846-044-209611sıra sayll karart ile izin alınmıştır Aksi bir durumun tespiti halinde AKAD Dergisinin hiçbir sorumluluğu olmayıp, tüm sorumluluk çalı̧̧manın yazar (lar) ina aittir.

Yazar Katkı Beyanı:1. Yazarın katkı oranı \%60, 2. Yazarın katkı oranı ise \%40’tır.

Çıkar Beyanı: Yazarlar arasında çıkar çatışması yoktur.

Ethics Statement: Permission for this study was obtained from the Ethics Committee of Istanbul Commerce University with the decision number E-65836846-044-209611 at the meeting dated 07/05/2021. In case of detection of a contrary situation, AKAD Journal has no responsibility and all responsibility belongs to the author (s) of the study.

Author Contributions Statement: 1st author's contribution rate 60\%, 2nd author's contribution rate $40 \%$.

Conflict of Interest: There is no conflict of interest among the authors.

\section{KAYNAKÇA}

Apaydın, Ç. (2011). Üyelerinin işe bağımlılık düzeyi ile iş yaşam dengesi ve iş aile yaşam arasındaki ilişki (Yayın No. 302868) [Doktora Tezi, Ankara Üniversitesi]. Yüksek Öğrenim Kurumu Tez Merkezi. https://tez.yok.gov.tr/UlusalTezMerkezi/tezSorguSonucYeni.jsp

Arslan, İ., \& Karagül, S. (2020, Mayıs). Küresel bir tehdit (COVID-19 Salgını) ve değişime yolculuk. Üsküdar Üniversitesi Sosyal Bilimler Dergisi, (10), 1-36. http://doi.org/10.32739/uskudarsbd.6.10.67

Avc1, A. (2019). İş ve iş stresi yönetimi. Avrasya Sosyal ve Ekonomi Araştırmaları Dergisi, 6(1), 290296. https://dergipark.org.tr/tr/download/article-file/635839

Ayyıldız, H., \& Cengiz, H. (2006). Pazarlama modellerinin testinde kullanılabilecek yapısal eşitlik modeli (YEM) üzerine kavramsal bir inceleme. Süleyman Demirel Üniversitesi, Iktisadi ve İdari Bilimler Fakültesi Dergisi, 11(1), 63-84. https://dergipark.org.tr/en/pub/sduiibfd/issue/20838/223311

Balc1, A. (2007). Sosyal bilimlerde araştırma yöntem, teknik ve ilkeler (6. Baskı). Pegem Akademi.

Bekmezci, M., Mert, İ. S., \& Abubakar, M. (2021). İş-yaşam dengesinin yaşam tatminini yordamasında çalışılan sektörün düzenleyici etkisi. Anadolu Üniversitesi Sosyal Bilimler Dergisi, 12(1), 1-22. https://dergipark.org.tr/en/download/article-file/1659851

Cognifit Research. (2021, May1s). Algl. https://www.cognifit.com/tr/perception

Cronbach, L. J. (1951). Coefficient alpha and the internal structure of tests. Psychometrika, 16(3), 297-334. https://doi.org/10.1007/BF02310555 
Demirbağ, A., Hasta, D., \& Çavdar, A. (2016). Siyasal görüş ve tehdit algısı arasındaki ilişkide sistemi meşrulaştırmanın aracı rolü. I. Sosyal Psikoloji Kongresi. Ankara. https://www.researchgate.net/publication/316140317_Siyasal_Gorus_ve_Tehdit_Algisi_Arasin daki_Iliskide_Sistemi_Mesrulastirmanin_Araci_Rolu

Duran, A. E. (2020). Işs hayatının yeni normali: Evden çalışma. DW.COM. https://www.dw.com/tr/ișhayatının-yeni-normali-evden-çalıșma/a-53219366

Elmas, M. (2013). Modern toplumun güvenlik çıkmazl: Tehdit, risk ve risk toplumu perspektifinden güvenlik. Usak Yayınları.

Ercan, İ., Kan, İ. (2004). Ölçeklerde güvenirlik ve geçerlik. Uludağ Üniversitesi Tip Fakültesi Dergisi, 30(3), 211-216. https://dergipark.org.tr/tr/download/article-file/420425

Erşan, E. E., Yıldırım, G., Doğan, O., \& Doğan, S. (2013). Sağlık çalışanlarının iş doyumu ve algılanan iş stresi ile aralarındaki ilişkinin incelenmesi. Anadolu Psikiyatri Dergisi, 14, 115-121. https://doi.org/10.5455/apd.34482

Fornell, C., \& Larcker D. (1981). Evaluating structural equation models with unobservable variables and measurement error. Journal of Marketing research, 18(1), 39-50. https://doi.org/10.2307/3151312

Göksu, Ö., \& Kumcağız, H. (2020). Covid-19 salgınında bireylerde algılanan stres düzeyi ve kaygı düzeyleri. Turkish Studies, 15(4), 463-479. https://doi.org/10.7827/TurkishStudies.44397

Günay, G. Y., \& Demiralay, T. (2016). Serbest muhasebeci ve müşavirlerin iş stresi, tükenmişlik sendromu ve iş-aile yaşam dengesi arasındaki iliş̧inin incelenmesi. Elektronik Sosyal Bilimler Dergisi, 15(58), 917-935. https://doi.org/10.17755/esosder.258826

Hair, Jr. J. F., Anderson, R. E., Tatham, R. L., \& Black, W. C. (2009). Multivariate data analysis. Prentice Hall.

Hatun, O., Dicle, A. N., \& Demirci, İ. (2020, Ağustos). Koronavirüs salgınının psikolojik yansımaları ve salgınla başa ç1kma. Turkish Studies, 15(4), 531-554, https://doi.org/10.7827/TurkishStudies.44364

Jöreskog, K. G., \& Sörbom, D. (1996). Lisrel 8: User's reference guide. Scientific Software.

Kaiser, H. F. (1974). An index of factorial simplicity. Psychometrika, 39, 31-36. https://doi.org/10.1007/BF02291575

Karabay, M. E. (2015). Sağlık personelinin iş stresi, iş-aile çatışması ve iş-aile-hayat tatminlerine yönelik algılarının işten ayrılma niyeti üzerindeki etkilerinin belirlenmesi üzerine bir araştırma. Yönetim Bilimleri Dergisi, 13(26), 113-134. https://dergipark.org.tr/tr/download/article$\underline{\text { file/660383 }}$

Korkmaz, A. (2017). Tehdit algısının sosyal hareketlere etkisi. Sosyoloji Konferanslart, 55, 479-483. https://doi.org/10.18368/iusoskon.328287

Korkmaz, O., \& Erdoğan, E. (2014, Ekim). İş yaşam dengesinin örgütsel bağlilık ve çalışan memnuniyetine etkisi. Ege Akademik Bakıs, 14(4), 541-557. https://dergipark.org.tr/en/download/article-file/560289

Köroğlu, Ö. (2011) İş doyumu ve motivasyon düzeylerini etkileyen faktörlerin performansla ilişkisi: Turist rehberleri üzerine bir araştırma (Yayın No. 279359) [Doktora Tezi, Balıkesir $\begin{array}{lllll}\text { Üniversitesi]. Ö̈̆renim } & \text { Yüksek Kurumu }\end{array}$ https://tez.yok.gov.tr/UlusalTezMerkezi/tezSorguSonucYeni.jsp

Küçükoğlu, M., \& Aksu, M. (2020). Covid-19 ve iş yaşamına etkileri: Evden çalışma. Journal of International Management, Educational and Economics Perspectives, 8(1), 71-81. https://dergipark.org.tr/tr/download/article-file/1163114 
Lin, T., \& Bautista, J. R. (2016) . Predicting intention to take protective measures during haze: The roles of efficacy, threat, media trust, and affective attitude. Journal of Health Communication, 21(7), 790-799. https://doi.org/10.1080/10810730.2016.1157657

Marteau, T. M., \& Berker, H. (1992). The development of a six-item short-form of the state scale of the spielberger state-trait anxiety inventory (STAI). British Journal of Clinical Psychology, 31(1), 301-306. https://doi.org/10.1111/j.2044-8260.1992.tb00997.x

Özdemir, İ. (2017). İş stresi ile iş-yaşam dengesi arasındaki ilişside işe bağglliğın rolü: Gemi adamları üzerine bir araştırma (Yayın No. 492897) [Yüksek Lisans Tezi, Marmara Üniversitesi]. $\quad$ Yüksek Öğrenim $\quad$ Kurumu $\quad$ Tez $\quad$ Merkezi. https://tez.yok.gov.tr/UlusalTezMerkezi/tezSorguSonucYeni.jsp

Özdemir, Y. A., Şahin Tekin, T., \& Esin, A. (2015). Çözümlü örneklerle örnekleme yöntemlerine giriş (1.bask1). Seçkin Kitabevi.

Raykov, T. (1997). Estimation of composite reliability for congeneric measures. Applied Psychological Measurement, 21(2), 173-182. https://doi.org/10.1177/01466216970212006

Saracel, P. D., Taşseven, D. D., \& Ay, N. (2015, Aralık). Örgütsel stresin iş motivasyonu üzerine etkisi: Banka çalışanlanı üzerine bir uygulama. Social Sciences Research Journal, 4(4), 12-34. https://dergipark.org.tr/tr/download/article-file/208863

Schermelleh-Engel, K., Moosbrugger, H., \& Müller, H. (2003). Evaluating the fit of structural equation models: Tests of significance and descriptive goodness-of-fit measures. Methods of $\begin{array}{lllll}\text { Psychological } & \text { Research } & \text { Online, } & \text { 8(2), } & 23-\end{array}$ http://www.stats.ox.ac.uk/ snijders/mpr_Schermelleh.pdf

Schumacker, R., E., \& Lomax, R. G. (2004). A beginner's guide to structural equation modelling, lawrance erlbaum associates. New Jersey.

Seferov, N. (2018, Aralık). Algılanan örgütsel stresin iş-yaşam dengesi ve kariyer başarısı ilişkisindeki aracılık rolü: Modern şirketler grubu yöneticileri örneği (Yayın No. 553175) [Yüksek Lisans Tezi, Muğla Sıtkı Koçman Üniversitesi]. Yüksek Öğrenim Kurumu Tez Merkezi. https://tez.yok.gov.tr/UlusalTezMerkezi/tezSorguSonucYeni.jsp

Sharma, S. (1996). Applied multivariate techniques. John Wiley \& Sons Inc.

Sönmez, R. V. (2020). COVID-19 kaygısının iş gören performansı motivasyonun üzerine etkisi: Hizmet sektöründe bir araştırma. Avrasya Sosyal ve Ekonomi Araştırmaları Dergisi, 7(12), 154-175. https://dergipark.org.tr/tr/download/article-file/1399818

Tabak, D. H. (2019). İş-yaşam dengesi ve stres: İstanbul'da ilçe belediyelerinde çalışanlar üzerinde bir araştırma (Yayın No. 566847) [Yüksek Lisans Tezi, Marmara Üniversitesi]. Yüksek Öğrenim Kurumu $\quad$ Tez https://tez.yok.gov.tr/UlusalTezMerkezi/tezSorguSonucYeni.jsp

Tavşancıl, E. (2002). Tutumların ölçülmesi ve SPSS ile veri analizi. Nobel Yayınevi.

TBB. (2020). COVID-19 pandemisi 4. ay değerlendirme raporu. Türk Tabipler Birliği. https://www.ttb.org.tr/kutuphane/covid19-rapor 4.pdf

Tekeli, S., \& Doğrul, B. Ş. (2010). İş-yaşam dengesinin sağlanmasında esnek çalışma. Sosyal ve Beşerî Bilimler Dergisi, 2(2), 11-18. https://dergipark.org.tr/tr/download/article-file/117237

Tekin, E. (2020). COVID-19 kaygısının motivasyon üzerindeki etkisi: Z kuşağı üzerine bir araştırma. Turkish Studies, 15(4), 1129-1145. https://doi.org/10.7827/TurkishStudies.44070

Tönbül, P. D. (2020). Koronavirüs (Covid-19) salgını sonrası 20-60 yaş arası bireylerin psikolojik dayanıklılıklarının bazı değişkenler açısından incelenmesi. Uluslararası Akademik Psikolojik Danışma ve Rehberlik Araştırmaları Dergisi, 2(2), 159-174. https://dergipark.org.tr/en/download/article-file/1154772 
Tuna, A. A., \& Türkmendağ, Z. (2020). Covid-19 pandemi döneminde uzaktan çalışma uygulamaları ve çalışma motivasyonunu etkileyen faktörler. İşletme Araştırmaları Dergisi, 12(3), 3246-3260. https://doi.org/10.20491/isarder.2020.1037

Uludağ, G. (2019). İş stresi ve motivasyon ilişkisine yönelik bir alan araştırması. Adıyaman Üniversitesi Sosyal Bilimler Enstitüsü Dergisi, $33, \quad 412-432$. https://doi.org/10.14520/adyusbd.605567

Uygun, H. (2015). İnsan kaynakları yönetiminde eğitim ve geliştirme faaliyetlerinin çalışan motivasyonuna etkileri ve sağllk sektöründen bir vaka analizi. (Yayın No. 391331) [Yüksek Lisans Tezi, İstanbul Gelişim Üniversitesi]. Yüksek Öğrenim Kurumu Tez Merkezi, https://tez.yok.gov.tr/UlusalTezMerkezi/tezSorguSonucYeni.jsp

Uysal, B., Ekici, M. A., Önal, A. C., \& Kulakoğlu, E. (2019). Psikolojik yıldırma (Mobing) ve çalışan motivasyonu arasındaki ilişkinin incelenmesi. Business \& Management Studies: An International Journal, 7(1), 280-307. https://doi.org/10.15295/bmij.v7i1.1066

Yang, Z. J. (2012). Too scared or too capable? Why do college students stay away from the H1N1 vaccine?. Risk Analysis: An International Journal, 32(10), 1703-1716. https://doi.org/10.1111/j.1539-6924.2012.01799.x

Yavuz, N., \& Doğan, A. (2018). İş stresinin iş-yaşam dengesi üzerindeki etkisinin esnek çalışma bağlamında test edilmesi. Istanbul Ticaret Üniversitesi Sosyal Bilimler Dergisi, 35, 41-62. http://acikerisim.ticaret.edu.tr/xmlui/bitstream/handle/11467/2665/M01237.pdf?sequence=1\&is Allowed=y

Yüce, G. E., \& Muz, G. (2021). COVID-19 pandemisinin yetişkinlerin diyet davranışları, fiziksel aktivite ve stres düzeyleri üzerine etkisi. Cukurova Medical Journal, 46(1), 283-291. http://doi.org/10.17826/cumj.794585 